INEL/EXT-97-00692

\title{
Dynamometer Tests of the Ford/TDM Ranger Electric Pickup Truck
}

\author{
G. H. Cole
}

E. J. Yarger

June 1997

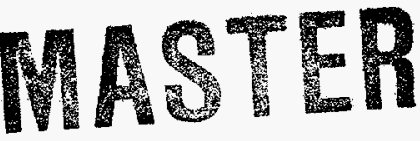

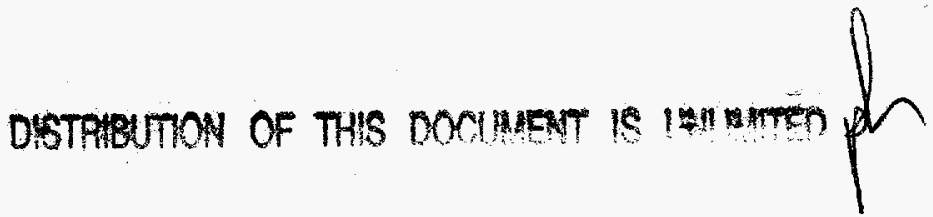

Prepared for the

U. S. Department of Energy

Assistant Secretary for Energy Efficiency and Renewable Energy (EE)

Under DOE Idaho Operations Office

Contract DE-AC07-94ID13223 


\section{DISCLAIMER}

This report was prepared as an account of work sponsored by an agency of the United States Government. Neither the United States Government nor any agency thereof, nor any of their employees, make any warranty, express or implied, or assumes any legal liability or responsibility for the accuracy, completeness, or usefulness of any information, apparatus, product, or process disclosed, or represents that its use would not infringe privately owned rights. Reference herein to any specific commercial product, process, or service by trade name, trademark, manufacturer, or otherwise does not necessarily constitute or imply its endorsement, recommendation, or favoring by the United States Government or any agency thereof. The views and opinions of authors expressed herein do not necessarily state or reflect those of the United States Government or any agency thereof. 


\section{DISCLAIMER}

Portions of this document may be illegible electronic image products. Images are produced from the best available original document. 


\begin{abstract}
A Ford Ranger electric vehicle was performance tested in the Idaho National Engineering and Environmental Laboratory (INEEL) Hybrid Electric Vehicle (HEV) Laboratory. The vehicle was converted by TDM, Inc. The test vehicle was delivered to the INEEL and tested for the California Air Resources Board (CARB) under a CRADA with the Department of Energy (DOE). Coastdown tests were performed to determine the vehicle road load versus speed characteristics and the results used to calibrate the chassis dynamometer. Tests included driving the vehicle on the chassis dynamometer using standard driving regimes to determine driving range, acceleration tests to determine full power acceleration times and gradeability at speed, and constant speed driving to determine the vehicle energy consumption at various speeds. Data during battery recharges was also acquired. This report presents the results of these tests.
\end{abstract}




\section{SUMMARY}

A Ford Ranger pickup truck which was converted to electric power by TDM, Inc. was tested in the INEEL HEV Laboratory. The test vehicle was delivered to the INEEL and tested for the California Air Resources Board (CARB) under a CRADA with the Department of Energy (DOE).

The following tables summarize the results of the tests performed.

Table S-1. Driving Cycle Tests.

\begin{tabular}{|l|l|l|l|}
\hline \multicolumn{1}{|c|}{ Test } & $\begin{array}{c}\text { Range } \\
(\mathbf{k m})\end{array}$ & $\begin{array}{c}\text { Net DC Energy } \\
\text { Consumption } \\
(\mathbf{W h / k m})\end{array}$ & $\begin{array}{c}\text { AC Energy } \\
\text { Consumption } \\
(\mathbf{W h} / \mathbf{k m})\end{array}$ \\
\hline All-Electric Range Test & $45.7-48.6$ & 284 & $\mathrm{NA}$ \\
\hline Urban Dynamometer Driving Schedule & $62.9-76.6$ & $284-315$ & 616 \\
\hline Highway Fuel Economy Driving Schedule & 64.5 & 274 & $\mathrm{NA}$ \\
\hline LA-92 Driving Schedule & 66.2 & 335 & $\mathrm{NA}$ \\
\hline
\end{tabular}

Table S-2. Acceleration/Gradeability

\begin{tabular}{|c|c|c|c|c|c|c|}
\hline \multirow{2}{*}{ Speed $(\mathbf{k m} / \mathbf{h})$} & \multicolumn{3}{|c|}{$\begin{array}{c}\text { Time (s) to attain speed at various } \\
\text { traction battery depths-of- } \\
\text { discharge }\end{array}$} & \multicolumn{3}{c|}{$\begin{array}{c}\text { Maximum Grade at Speed (\%) at } \\
\text { various traction battery depths-of- } \\
\text { discharge }\end{array}$} \\
\cline { 2 - 7 } & $\mathbf{2 . 8 \%}$ & $\mathbf{4 5 . 3 \%}$ & $\mathbf{6 6 . 9 \%}$ & $\mathbf{2 . 8 \%}$ & $\mathbf{4 5 . 3 \%}$ & $\mathbf{6 6 . 9 \%}$ \\
\hline 24 & 2.1 & 2.1 & 3.7 & 39.2 & 38.4 & 16.3 \\
\hline 32 & 2.8 & 2.9 & 5.1 & 39.0 & 28.7 & 15.4 \\
\hline 40 & 3.5 & 3.8 & 7.0 & 27.0 & 21.4 & 11.1 \\
\hline 48 & 4.5 & 5.1 & 9.5 & 20.7 & 16.6 & 8.7 \\
\hline 56 & 5.8 & 6.7 & 12.7 & 15.1 & 12.2 & 5.5 \\
\hline 64 & 7.6 & 8.8 & 17.1 & 11.9 & 10.1 & 4.6 \\
\hline 72 & 9.9 & 11.5 & 23.0 & 8.7 & 9.1 & 3.4 \\
\hline 80 & 13.0 & 14.9 & 31.6 & 6.0 & 5.5 & 2.3 \\
\hline 88 & 17.6 & 19.9 & 47.0 & 4.0 & 3.7 & 0.9 \\
\hline 96 & 24.6 & 28.2 & & 2.6 & 2.3 & \\
\hline
\end{tabular}


Table S-3. Energy consumption and traction battery power at steady speed.

\begin{tabular}{|c|c|c|c|c|}
\hline \multirow{2}{*}{ Speed $(\mathbf{k m} / \mathbf{h})$} & \multicolumn{2}{|c|}{$\begin{array}{c}\text { Starting at 0\% traction battery } \\
\text { depth-of-discharge }\end{array}$} & \multicolumn{2}{c|}{$\begin{array}{c}\text { Starting at 50\% traction battery } \\
\text { depth-of-discharge }\end{array}$} \\
\cline { 2 - 5 } & $\begin{array}{c}\text { Energy } \\
\text { Consumption } \\
(\mathbf{D C} \mathbf{~ W h / k m )}\end{array}$ & $\begin{array}{c}\text { Battery Power } \\
\text { (DC } \mathbf{~ k W})\end{array}$ & $\begin{array}{c}\text { Energy } \\
\text { Consumption DC } \\
\mathbf{W h} / \mathbf{k m}\end{array}$ & $\begin{array}{c}\text { Battery Power } \\
\text { DC kW }\end{array}$ \\
\hline 16 & 268 & 4.3 & 216 & 3.7 \\
\hline 32 & 239 & 7.8 & 195 & 6.4 \\
\hline 40 & 225 & 9.0 & 188 & 7.7 \\
\hline 48 & 217 & 10.4 & 190 & 9.2 \\
\hline 56 & 223 & 12.6 & 201 & 11.3 \\
\hline 64 & 233 & 15.0 & 216 & 13.8 \\
\hline 72 & 246 & 17.8 & 231 & 16.8 \\
\hline 80 & 267 & 21.5 & 253 & 20.3 \\
\hline 88 & 288 & 25.4 & 276 & 24.4 \\
\hline 96 & 315 & 30.2 & 316 & 30.1 \\
\hline
\end{tabular}




\section{CONTENTS}

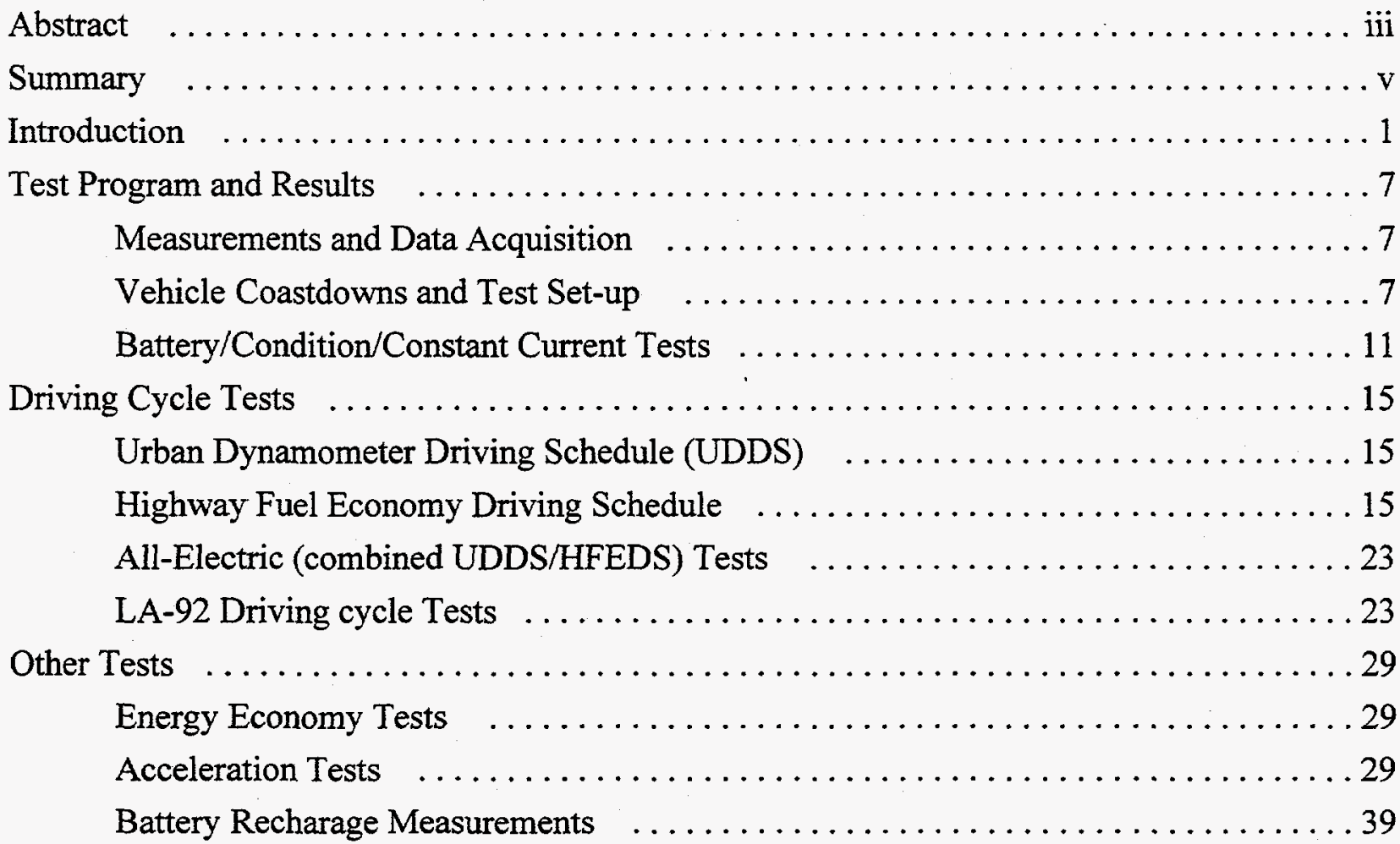

\section{TABLES}

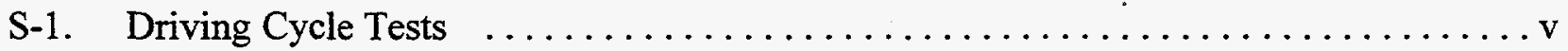

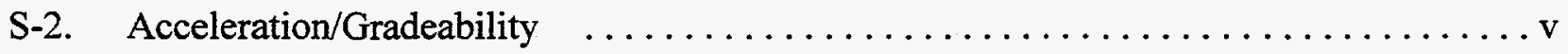

S-3. Energy consumption and traction battery power at steady speed $\ldots \ldots \ldots \ldots \ldots$ vi

1. TDM/Ford Ranger characteristics and specifications $\ldots \ldots \ldots \ldots \ldots \ldots \ldots \ldots \ldots \ldots$

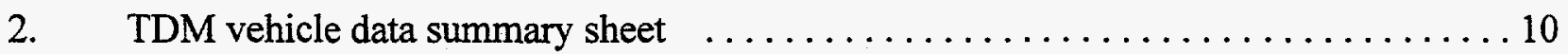

3a. Results of UDDS (combined cycles) prior to repairs made by TDM $\ldots \ldots \ldots \ldots 17$

3b. Results of UDDS (separate cycles) prior to repaiars made by TDM $\ldots \ldots \ldots \ldots \ldots 17$

4a. Results of UDDS (combined cycles 0 subsequent to repairs made by TDM $\ldots \ldots 18$

4b. Results of UDDS (separate cycles ) subsequent to repairs made by TDM $\ldots \ldots \ldots 18$

5a. Results of UDDS (combined cycles) with simulated AC load $\ldots \ldots \ldots \ldots \ldots \ldots$

5b. Results of UDDS (separate cycles) with simulated AC load $\ldots \ldots \ldots \ldots \ldots \ldots$

6a. Results of UDDS (separate cycles) with AC on max., min., and off $\ldots \ldots \ldots \ldots \ldots 20$

6b. Results of UDDS (combined cycles) with AC on max., min., and off $\ldots \ldots \ldots \ldots 20$

7. Results of Highway Fuel Economy Driving Schedule testing $\ldots \ldots \ldots \ldots \ldots \ldots 21$ 
8a. Results of All-Electric (combined UDDS/HFEDS) (Cycle 1 \& 2) [LTDMA106] . . . 25

8b. Results of All-Electric (combined UDDS/HFEDS) Testing [LTDMA106] $\ldots \ldots \ldots 25$

9a. Results of All-Electric (combined UDDS/HFEDS) (Cycle 1\&2) [LTDMA108] . . .. 26

9b. Results of All-Electric (combined UDDS/HFEDS) Testing [LTDMA108] . . . . . 26

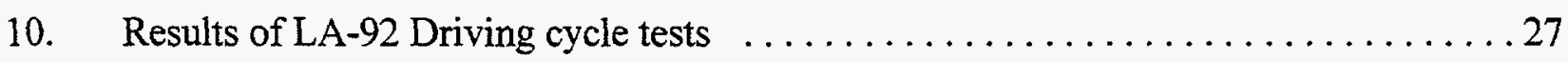

11. Acceleration times to reach a specified speed \& calculated gradeability-at-speed ...35

12. Traction battery $\mathrm{DC}$ energy consumption at steady speeds $\ldots \ldots \ldots \ldots \ldots \ldots \ldots$

\section{FIGURES}

1. TDM/Ford Ranger test vehicle on the chassis dynamometer at the INEEL $\ldots \ldots \ldots 2$

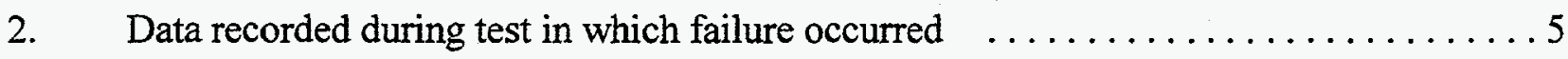

3. Data recorded during test in which failure occurred $\ldots \ldots \ldots \ldots \ldots \ldots \ldots$

4. Schematic diagram showing the location of current shunts placed on the vehicle $\ldots .99$

5. Typical traction battery recharge data prior to repairs made by TDM $\ldots \ldots \ldots 13$

6. Typical traction battery recharge data after repairs made by TDM $\ldots \ldots \ldots \ldots \ldots 14$

7. Comparison of energy consumption as reported by TDM $\ldots \ldots \ldots \ldots \ldots \ldots \ldots \ldots \ldots \ldots$

8. Results of energy consumption test prior to vehicle repairs $\ldots \ldots \ldots \ldots \ldots \ldots \ldots \ldots \ldots$

9. Results of energy consumption tests subsequent of vehicle repairs $\ldots \ldots \ldots \ldots \ldots 33$

10. Maximum effort acceleration time to attain speed at various traction battery DODs . . 37

11. Percent gradeability at speed derived from maximum effort acceleration tests . ...41

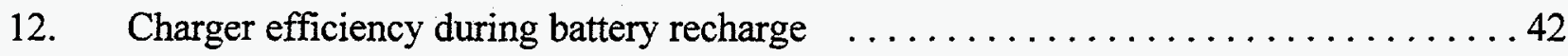




\section{DYNAMOMETER TESTS \\ OF THE \\ FORD/TDM RANGER ELECTRIC PICKUP TRUCK}

\section{INTRODUCTION}

This report presents the results of dynamometer tests performed in the INEEL Hybrid/Electric Vehicle Laboratory on an electrically powered Ford/TDM Ranger pickup truck. The intent of these tests was to determine the performance of the vehicle under standard driving regimes. By measuring significant parameters under these driving regimes, information was obtained by which the overall vehicle performance may be compared to other electric vehicles, The performance of vehicle subsystems may also be judged.

The Ford/TDM Ranger electric vehicle was received at the INEEL on October 16, 1996. Tests were performed during the period from October 30, 1996 through January 31, 1997. A photograph of the vehicle is shown in Figure 1. The salient characteristics and other specifications of the test vehicle are provided in Table 1.

During the test program, a catastrophic failure occurred while performing an all-electric (combined UDDS and HFEDS) driving cycle test. The failure occurred at approximately 180 seconds into the test during the initial stop-start portion of the UDDS segment. The failure was unexpected and there were no prior indications of abnormal operation. It appeared to test personnel that a sudden power loss had occurred. Since there was no motive power, test personnel then brought the vehicle to a stop. Figures 2 and 3 show the data that were recorded during the test. The failure occurred while the vehicle speed was $77 \mathrm{~km} / \mathrm{h}$ and accelerating at a moderate rate. The battery voltage and current just prior to the event was $312.8 \mathrm{~V}$ and $89.7 \mathrm{~A}$, respectively. The battery power measured at this point was $28.1 \mathrm{~kW}$.

After an initial inspection of the vehicle, TDM personnel were contacted. Our initial inspection included removal of the controller cover. Upon removal of the cover, test personnel noted the characteristic odor of electronic component failures. Some discoloration inside the controller cover and above one of the high power electronic components was noted.

After further diagnosis in consultation with TDM personnel, it was determined that the damage was quite extensive and could not be practically repaired at INEEL. Subsequently the vehicle was shipped to TDM for more detailed diagnosis, analysis and repair on November 24, 1996. 
The repaired vehicle was returned to INEEL on December 14, 1996 and testing was resumed. The results of the tests performed prior to the repairs differ from those performed after the repairs. Most notable is the difference in the traction battery charge behavior.

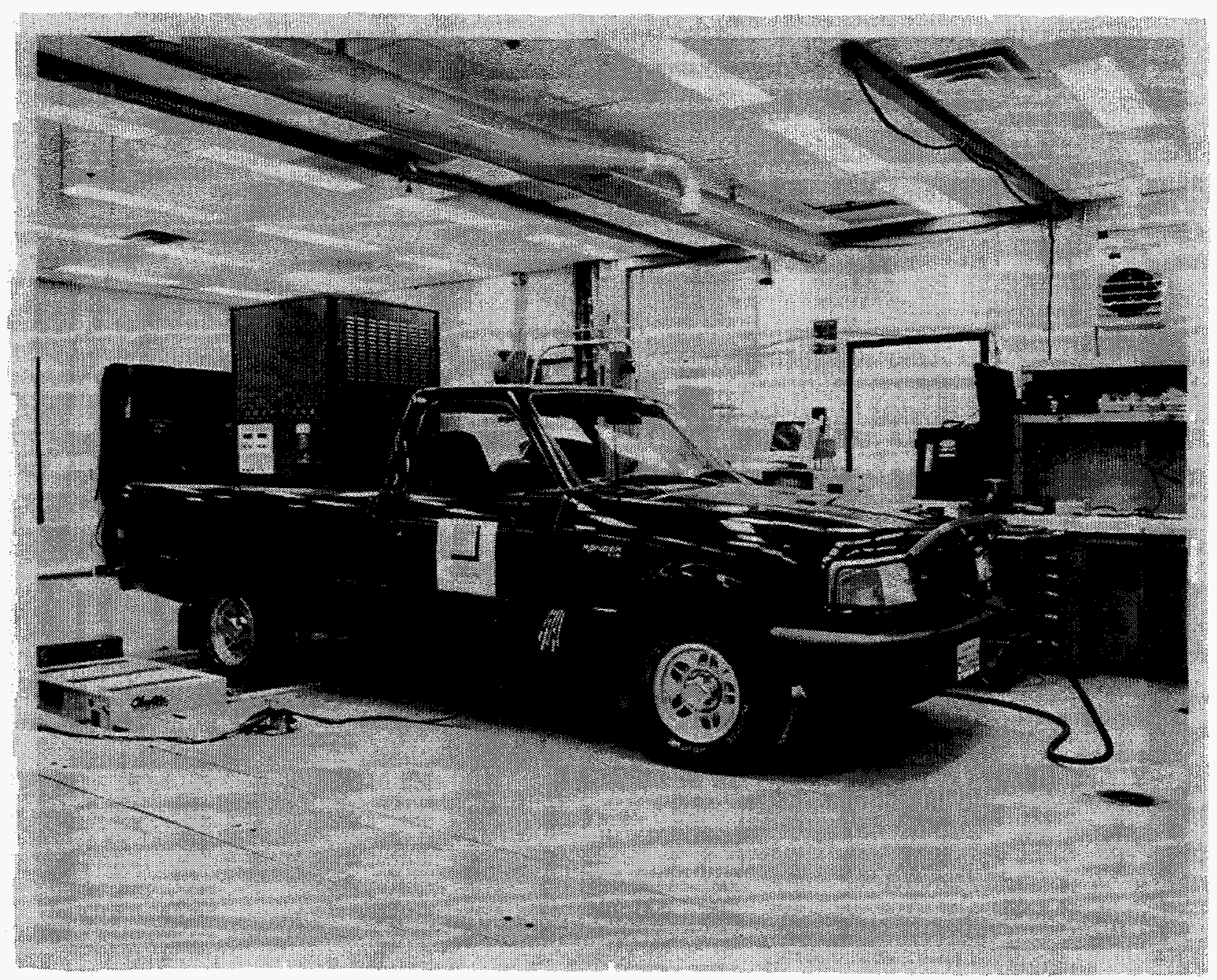

Figure 1. TDM/Ford Ranger test vehicle on the chassis dynamometer at the INEEL. [97-0008-1-5] 
Table 1. TDM/Ford Ranger characteristics and specifications.

\begin{tabular}{|c|c|}
\hline Base Vehicle & Ford Ranger Pickup Truck \\
\hline Model Year & 1996 \\
\hline Color & Red \\
\hline VIN & 1FFDR1007TTA30129 \\
\hline Overall Length & $5004 \mathrm{~mm}$ \\
\hline Overall Width & $1702 \mathrm{~mm}$ \\
\hline Overall Height & $1626 \mathrm{~mm}$ \\
\hline Wheelbase & $2921 \mathrm{~mm}$ \\
\hline Track & $1676 \mathrm{~mm}$ front $/ 1727 \mathrm{~mm}$ rear \\
\hline Curb Weight & $2304 \mathrm{~kg}$ \\
\hline Test Weight & $2440 \mathrm{~kg}$ \\
\hline Weight Distribution & $1016 \mathrm{~kg}$ front $/ 1288 \mathrm{~kg}$ rear \\
\hline Tires & Michelin P225/70 R14 \\
\hline Drive line & $\begin{array}{l}\text { Rear wheel drive, Westinghouse } 3 \phi \text { AC Induction Motor, single } \\
\text { speed transmission }\end{array}$ \\
\hline Battery & $\begin{array}{l}28 \times 12 \mathrm{~V}, 80 \text { Ah GNB sealed lead acid modules arranged in } \\
\text { series and divided into two battery packs. One pack located } \\
\text { under the cargo floor and one located in the truck bed. }\end{array}$ \\
\hline Charger & Input: 208 or $220 \mathrm{VAC}, 18 \mathrm{~A}$ maximum \\
\hline Features & $\begin{array}{l}\text { Air conditioning, power steering, power brakes (front disc), tilt } \\
\text { steering wheel }\end{array}$ \\
\hline
\end{tabular}




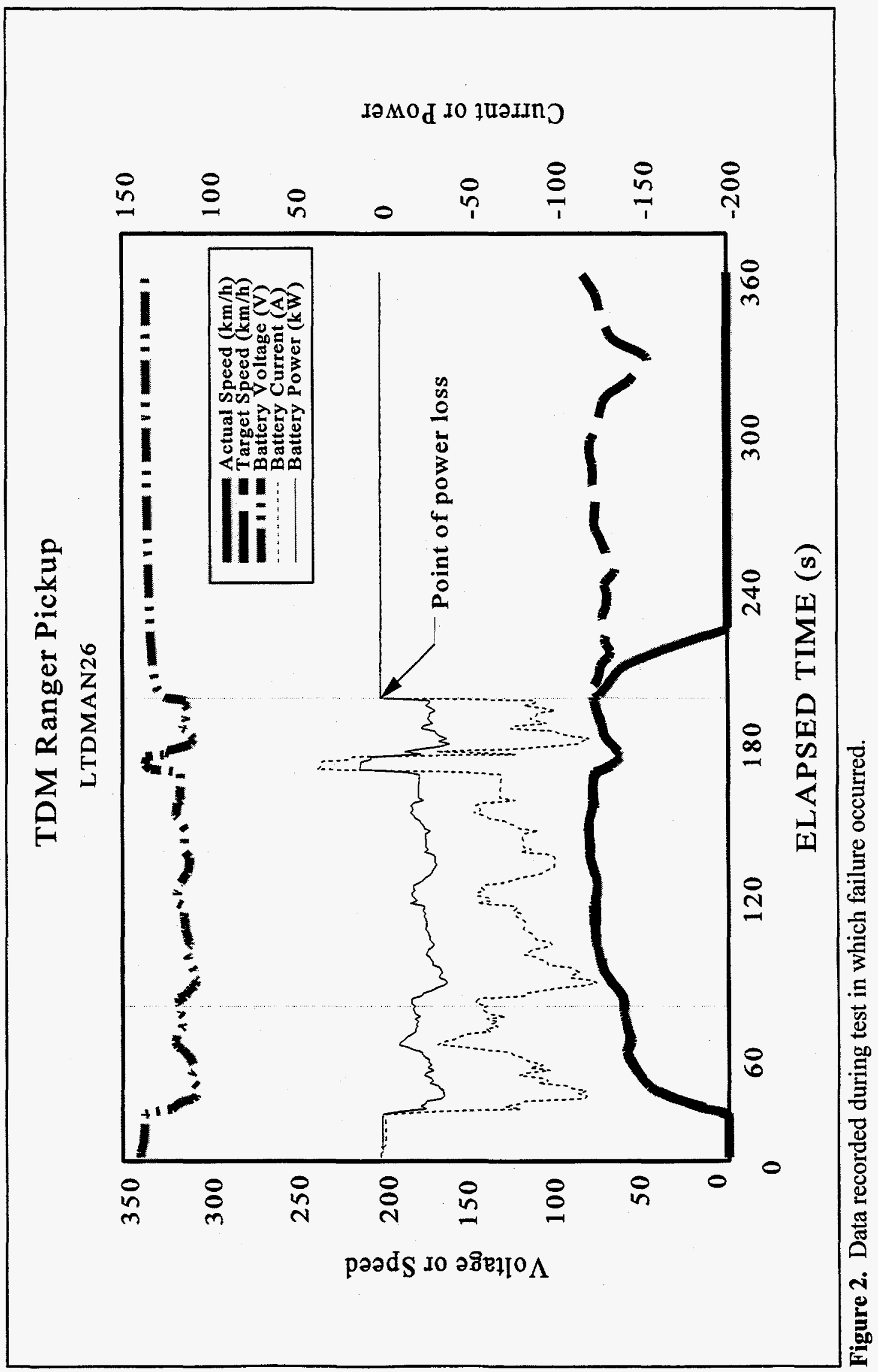




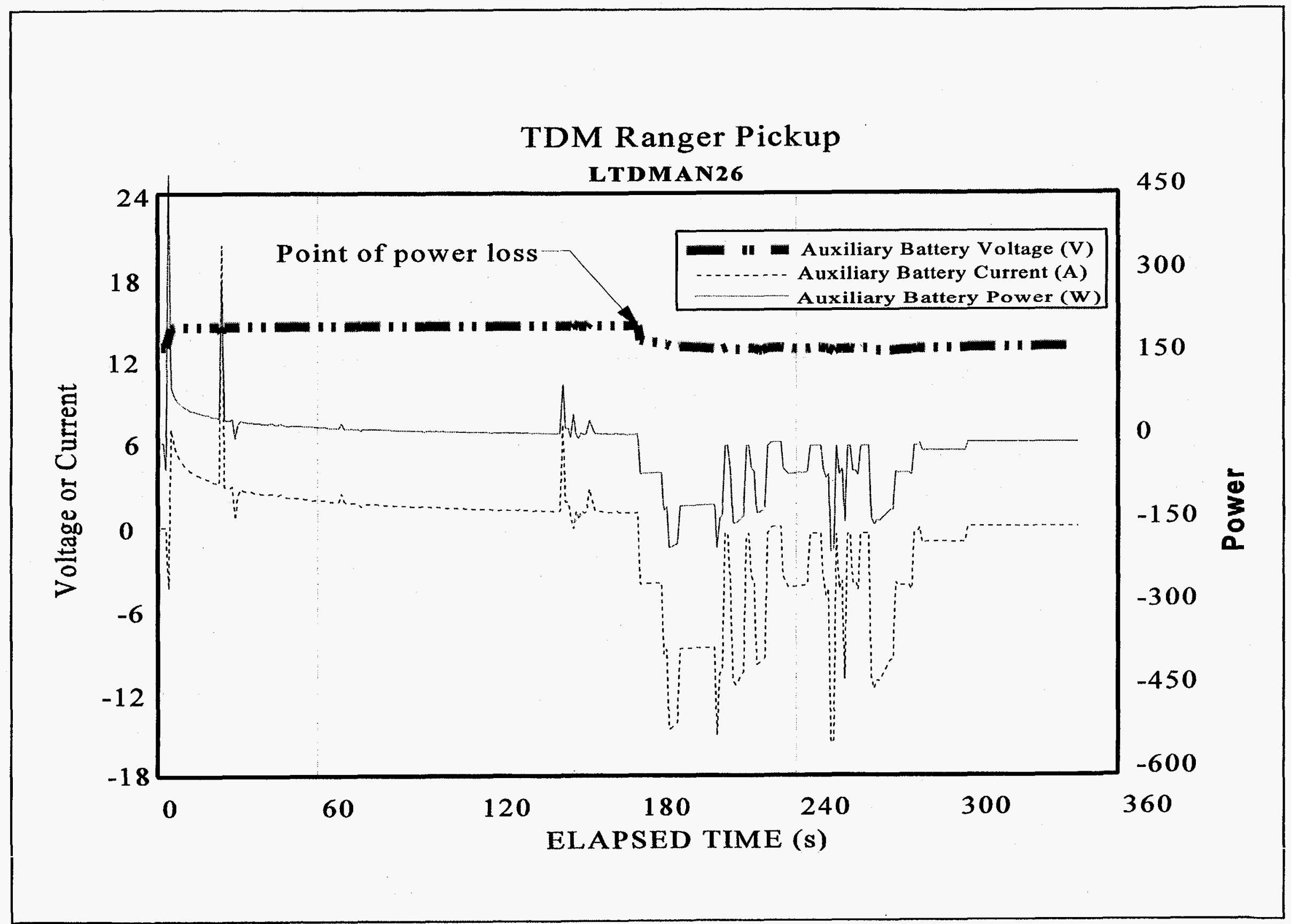

Figure 3. Data recorded during test in which failure occurred. 


\section{TEST PROGRAM AND RESULTS}

\section{Measurements and Data Acquisition}

In total, 15 dynamometer tests were performed during the period from November 19 , 1996 and January 31, 1997. These tests included tests to determine the energy consumption at various steady speeds, constant battery current tests to ascertain the traction battery capacity, maximum effort acceleration tests, and driving schedule tests. The driving schedule tests performed included the Urban Dynamometer Driving Schedule (UDDS), Highway Fuel Economy Driving schedule (HFEDS), LA-92 schedule and the combined UDDS/HFEDS driving schedules. Driving schedule tests are performed to determine the vehicle range on a single charge on these standard speed-time profiles.

Measurements were made using calibrated instruments, and acquired with either of two data acquisition systems. On-road data was acquired and recorded using the INEEL-developed Versatile Data Acquisition System (VDAS). Tests performed on the chassis dynamometer were acquired using the INEEL Laboratory Data Acquisition System (LDAS). Data for most driving tests were recorded at one second intervals. The schematic diagram of Figure 4 shows the location of the current shunts placed on the vehicle for current measurements.

Test numbers coincide with filenames of the INEEL standard format data files for each test. The Vehicle Test Data Summary Sheet shown in Table 2 provides a summary of the information contained in the data files archived at the INEEL.

\section{Vehicle Coastdowns and Test Set Up}

The road loads programmed into the dynamometer were determined from coastdown trials performed at the INEEL. Speed-time data was acquired using a fifth wheel and recorded at 0.1 second intervals using the VDAS. Coastdowns were performed at a vehicle test weight of $2440 \mathrm{~kg}(5380 \mathrm{lb}$.) with all drive line components and brakes in their normal configuration. A total of twelve coastdown trials were performed which resulted in four paired runs (i.e., eight coastdown runs). The data from these coastdown runs were reduced according to SAE J1634 to determine the road load vs. speeds relationship for a dynamometer setup. The resultant road load 
force equation (corrected to standard conditions and accounting for non-rotating inertia) used for determining the set points on the chassis dynamometer is given by the following equation.

$$
\mathrm{F}(\mathrm{N})=324.21(\mathrm{~N})+0.06965\left(\mathrm{~N} / \mathrm{km}^{2}\right) \mathrm{v}^{2}
$$

Application of the above equation yields the following dynamometer coastdown times:

Speed

88 to $72 \mathrm{~km} / \mathrm{h}$

96 to $16 \mathrm{~km} / \mathrm{h}$

32 to $16 \mathrm{~km} / \mathrm{h}$

\section{Time}

$14.34 \mathrm{sec}$

$104.66 \mathrm{sec}$

$30.16 \mathrm{sec}$ 


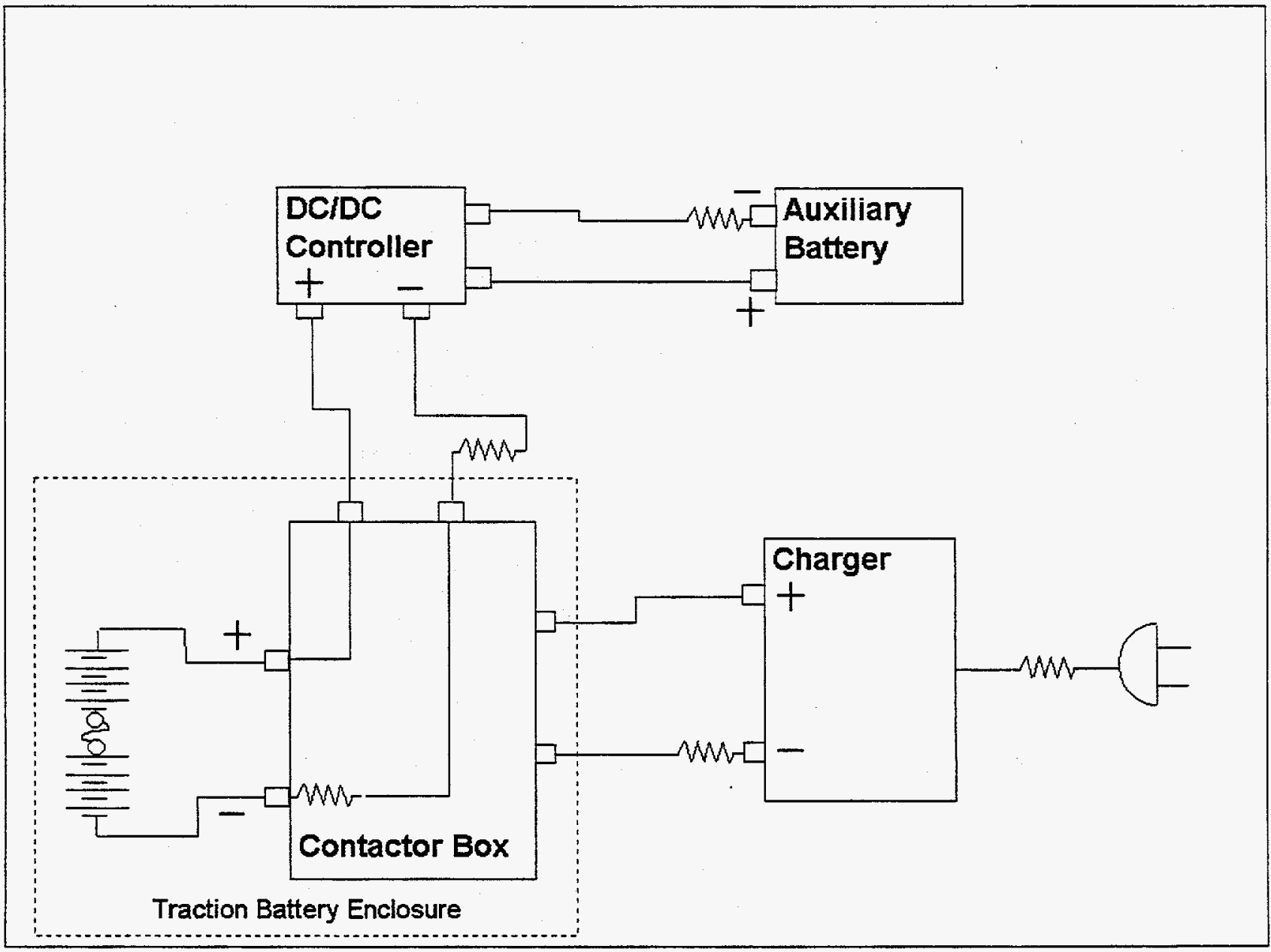

Figure 4. Schematic diagram showing location of current shunts placed on the vehicle. 
Table 2. TDM vehicle data summary sheet.

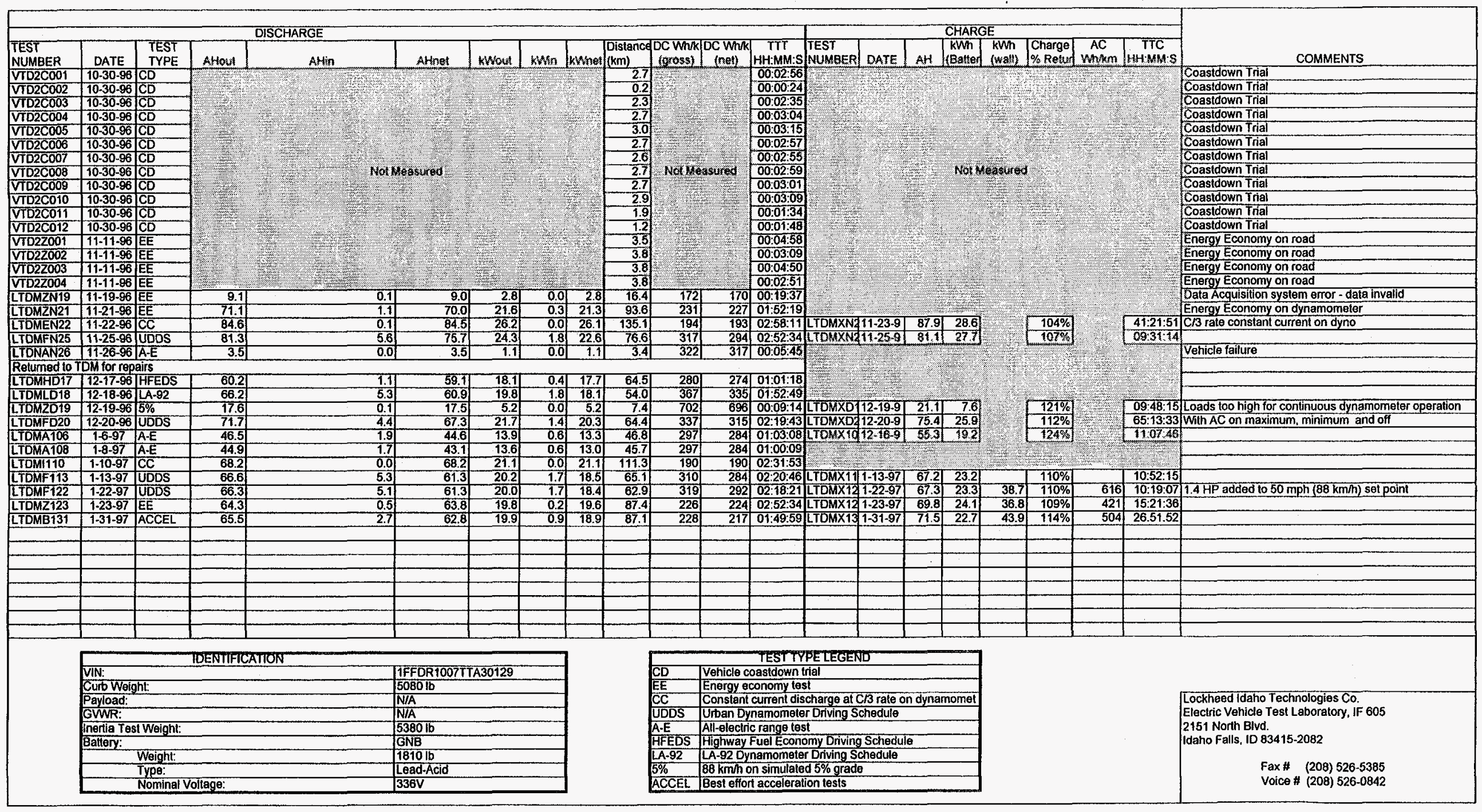




\section{Battery Condition/Constant Current Tests}

Two constant current discharge tests were performed to investigate the battery condition. One test was performed prior to the repairs and one after the repairs were performed by TDM. The vehicle was driven on the chassis dynamometer such that a constant current at the $\mathrm{C} / 3$ rate $(27 \mathrm{~A})$ from the traction battery was maintained as closely as possible. The discharge was completed when the vehicle automatically shut down.

Results of these two tests differ significantly. Prior to the vehicle repairs, 84.5 net Ah were removed from the battery after a full charge. When this test was repeated, 68.2 net Ah were removed. Prior to the repairs made by TDM the vehicle battery monitoring system would measure all of the cell voltages and initial battery temperature and then calculate the charging algorithm using this information. TDM personnel felt that this method could over charge some modules. During the repairs at TDM, the calculation of the charging algorithm was changed by "floating" the modules that were 2.5 to 2.6 volts per cell adjusting the algorithm as a function of the current battery temperature. It was also reported that the battery manufacturer, GNB, modified the battery heater system while the vehicle was at TDM.

It is unclear from the information available if the difference in apparent battery capacity before and after the repair is due to degradation of the battery electrochemistry or changes made by TDM and GNB when they repaired the vehicle. However, the following observations regarding battery charging are made:

- The open circuit voltages at the start of the constant current discharge prior to the repairs was measured to be $336.5 \mathrm{~V}$, and $331.2 \mathrm{~V}$ after the repairs.

- $\quad$ The voltage under load just prior to shut down prior to the repairs was $274.3 \mathrm{~V}$ while the voltage after the repairs was $285.8 \mathrm{~V}$.

- The charge algorithm was changed during the time the vehicle was at TDM. Figures 5 and 6 show the typical battery charge behavior before and after the repairs. Note that after the repairs, the end-of-charge voltage was lower and that the charge current at the end-of-charge voltage was not held for as long a period of time. 


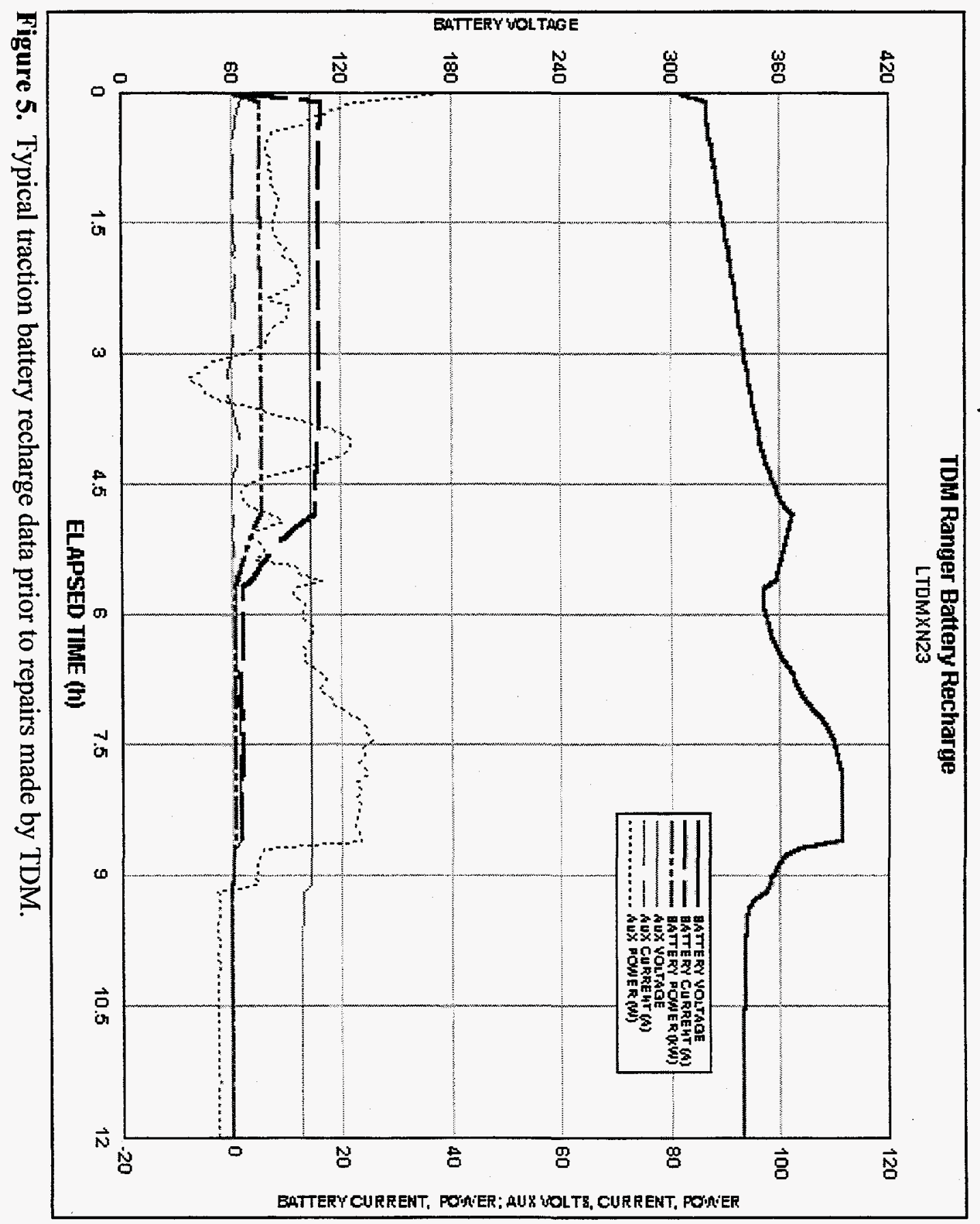




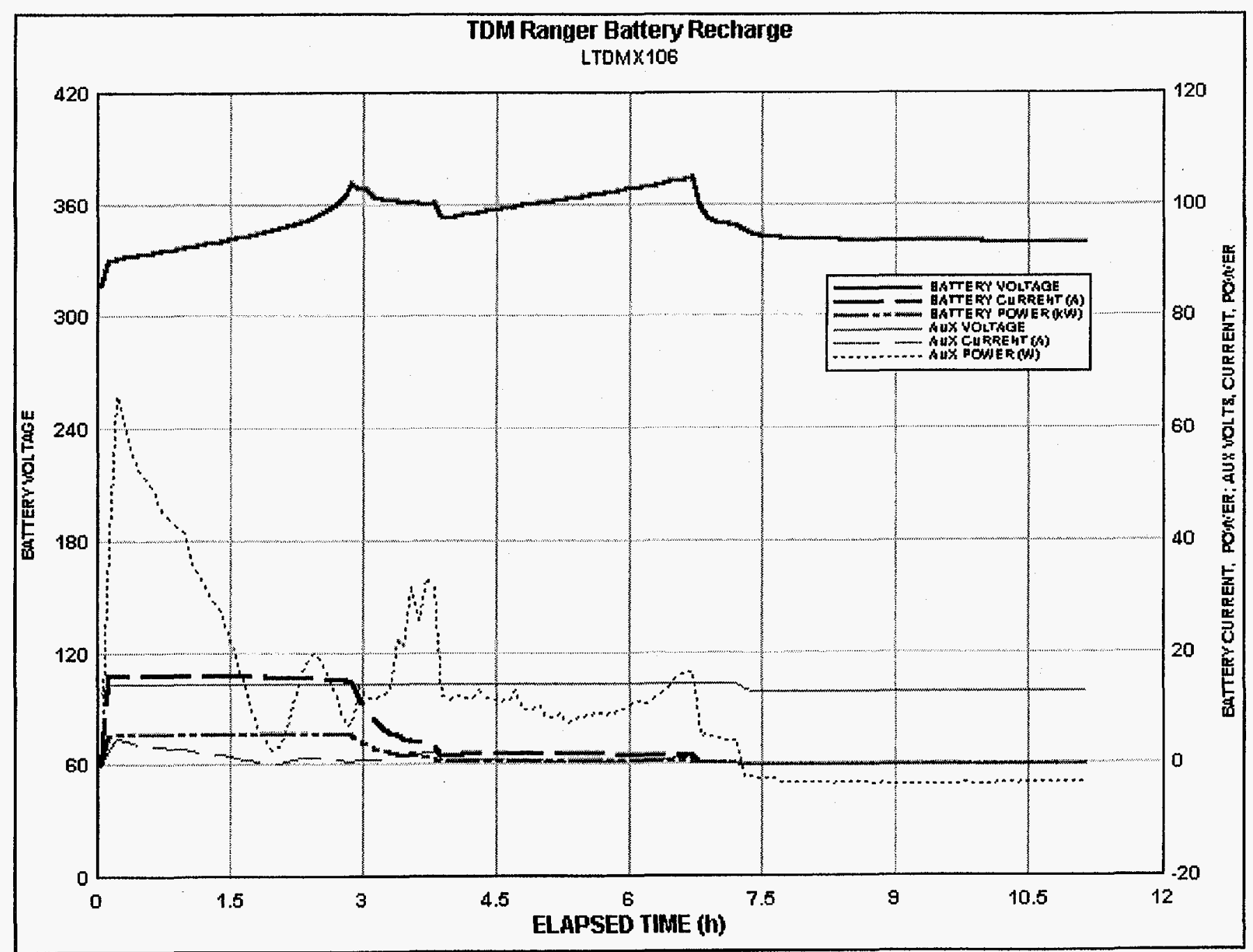

Figure 6. Typical traction battery recharge data after repairs made by TDM. 


\section{DRIVING CYCLE TESTS}

All driving cycle range tests were terminated when the vehicle shut itself off after sensing a depleted battery. In most instances, this occurred shortly after the performance criteria specified by SAE J1634, "Electric Vehicle Energy Consumption and Range Test Procedure," was realized.

\section{Urban Dynamometer Driving Schedule (UDDS)}

One Urban Dynamometer Driving Schedule (UDDS) test was performed prior to the vehicle repairs (test number LTDMFN25) and one after the repairs (test number LTDMF113). The results of these respective tests are shown in Tables $3 a, 3 b, 4 a$ and $4 b$, respectively.

Two additional UDDS tests were performed to ascertain the effect of the vehicle air conditioning on vehicle performance. Test number LTDMF 122 was performed as in the standard UDDS test with a load equivalent to 1.4 horsepower added to the dynamometer load at $88 \mathrm{~km} / \mathrm{h}$. Summarized results of this test are shown in Tables $5 \mathrm{a}$ and $5 \mathrm{~b}$.

In order to better ascertain the effect of air conditioning, a modified UDDS test was defined. In this test (test number LTDMFD20), the air vehicle air conditioner was set to "maximum" for the first two UDDS sub-cycles, "minimum" for the third and fourth subcycles, and "off" for the remainder of the discharge. For the "maximum" cooling condition, the air condition controls were set for the coldest air temperature and the fan at its highest setting. For the "minimum" cooling condition, the air temperature was set at the coolest setting and the fan was set at its lowest setting. During this test, the vehicle windows were open and the ambient temperature ranged between $19.4^{\circ} \mathrm{C}$ and $22.1^{\circ} \mathrm{C}$. Tables $6 \mathrm{a}$ and $6 \mathrm{~b}$ provides summary results of this test.

\section{Highway Fuel Economy Driving Schedule}

One Highway Fuel Economy Driving Schedule (HFEDS) driving profile test was performed (test number LTDMD17). Cycle-by-cycle results are given in Table 7. 
Table 3a. Results of UDDS Test No. LTDMFN25 (combined cycles) prior to repairs made by TDM.

\begin{tabular}{|c|c|c|c|c|c|}
\hline \multicolumn{6}{|c|}{ Federal Urban Driving Schedule Test Results } \\
\hline \multirow[b]{3}{*}{ General: } & \multicolumn{5}{|c|}{ Cycle Number } \\
\hline & $1-2$ & $3-4$ & $5-6$ & $7^{*}$ & Total \\
\hline & & & & & \\
\hline Distance $(\mathrm{km})$ & 24.2 & 24.2 & 24.3 & 4.1 & 76.6 \\
\hline Vehicle DC Energy Consumption (Wh/km) & 299 & 293 & 289 & 286 & 294 \\
\hline Gross Ampere-hours (Ah) & 25.2 & 25.1 & 26.0 & 4.9 & 81.3 \\
\hline Regen Ampere-hours (Ah) & 1.8 & 1.7 & 1.8 & 0.3 & 5.6 \\
\hline Net Ampere-hours (Ah) & 23.3 & 23.4 & 24.3 & 4.6 & 75.7 \\
\hline Gross DC Energy (kWh) & 7.8 & 7.6 & 7.6 & 1.3 & 24.3 \\
\hline Regen DC Energy (kWh) & 0.6 & 0.6 & 0.6 & 0.1 & 1.8 \\
\hline Net DC Energy (kWh) & 7.2 & 7.1 & 7.0 & 1.2 & 22.5 \\
\hline \multicolumn{6}{|l|}{ Driving Cycle Discharge Information: } \\
\hline Minimum Battery Voltage $(M)$ & 283.9 & 272.7 & 254.4 & 233.8 & 233.8 \\
\hline Maximum Battery Current $(A)$ & 260.3 & 275.0 & 158.4 & 158.2 & 275.0 \\
\hline Maximum Battery Power $(\mathrm{kW})$ & 73.9 & 75.0 & 45.1 & 40.5 & 75.0 \\
\hline \multicolumn{6}{|l|}{ Driving Cycle Regen Information: } \\
\hline Maximum Battery Voltage $(V)$ & 356.7 & 336.7 & 328.2 & 320.4 & 356.7 \\
\hline Maximum Battery Current (A) & 73.0 & 80.2 & 68.6 & 54.5 & 80.2 \\
\hline Maximum Battery Power (kW) & 34.3 & 27.0 & 22.5 & 17.5 & 34.3 \\
\hline
\end{tabular}

Table 3b. Results of UDDS Test No. LTDMFN25 (separate cycles) prior to repairs made by TDM.

\begin{tabular}{|c|c|c|c|c|c|c|c|c|}
\hline \multicolumn{9}{|c|}{ Federal Urban Driving Schedule Test Results } \\
\hline & \multicolumn{8}{|c|}{ Cycle Number } \\
\hline & 1 & 2 & 3 & 4 & 5 & 6 & $7^{*}$ & Total \\
\hline \multicolumn{9}{|l|}{ General: } \\
\hline Distance $(\mathrm{km})$ & 12.1 & 12.1 & 12.1 & 12.1 & 12.1 & 12.1 & 4.1 & 76.6 \\
\hline Vehicle DC Energy Consumption (Wh/km) & 305 & 292 & 295 & 291 & 292 & 288 & 286 & 294 \\
\hline Gross Ampere-hours (Ah) & 12.9 & 12.3 & 12.6 & 12.6 & 12.9 & 13.2 & 4.9 & 81.3 \\
\hline Regen Ampere-hours (Ah) & 1.0 & 0.9 & 0.8 & 0.8 & 0.9 & 0.9 & 0.3 & 5.6 \\
\hline Net Ampere-hours (Ah) & 11.9 & 11.4 & 11.7 & 11.7 & 12.0 & 12.3 & 4.6 & 75.7 \\
\hline Gross DC Energy (kWh) & 4.0 & 3.8 & 3.8 & 3.8 & 3.8 & 3.8 & 1.3 & 24.3 \\
\hline Regen DC Energy (kWh) & 0.3 & 0.3 & 0.3 & 0.3 & 0.3 & 0.3 & 0.1 & 1.8 \\
\hline Net DC Energy (kWh) & 3.7 & 3.5 & 3.6 & 3.5 & 3.5 & 3.5 & 1.2 & 22.5 \\
\hline \multicolumn{9}{|l|}{ Driving Cycle Discharge Information: } \\
\hline Minimum Battery Voltage $(V)$ & 286.9 & 283.9 & 283.4 & 272.7 & 279.0 & 254.4 & 233.8 & 233.8 \\
\hline Maximum Battery Current $(A)$ & 239.8 & 260.3 & 236.9 & 275.0 & 158.4 & 158.3 & 158.2 & 275.0 \\
\hline Maximum Battery Power (kW) & 68.8 & 73.9 & 67.1 & 75.0 & 45.1 & 43.4 & 40.5 & 75.0 \\
\hline \multicolumn{9}{|l|}{ Driving Cycle Regen Information: } \\
\hline Maximum Battery Voltage (V) & 356.7 & 339.6 & 336.7 & 330.5 & 328.2 & 323.0 & 320.4 & 356.7 \\
\hline Maximum Battery Current (A) & 73.0 & 55.9 & 80.2 & 52.8 & 68.6 & 58.0 & 54.5 & 80.2 \\
\hline Maximum Battery Power ( $\mathrm{kW}$ ) & 34.3 & 18.8 & 27.0 & 17.0 & 22.5 & 18.7 & 17.5 & 34.3 \\
\hline
\end{tabular}


Table 4a. Results of UDDS Test No. LTDMF113 (combined cycles) subsequent to repairs made by TDM.

\begin{tabular}{|c|c|c|c|c|}
\hline Federal Urb & n Drivi & ng Sche & dule $\mathrm{Te}$ & \\
\hline & & & ycle N & \\
\hline & 1.2 & $3-4$ & $5-6^{*}$ & Total \\
\hline General: & & & & \\
\hline Distance $(\mathrm{km})$ & 24.2 & 24.1 & 16.9 & 65.1 \\
\hline Vehicle DC Energy Consumption (Wh/km) & 292 & 279 & 279 & 284 \\
\hline Gross Ampere-hours (Ah) & 24.7 & 24.2 & 17.6 & 66.6 \\
\hline Regen Ampere-hours (Ah) & 1.9 & 2.0 & 1.4 & 5.3 \\
\hline Net Ampere-hours (Ah) & 22.8 & 22.2 & 16.2 & 61.3 \\
\hline Gross DC Energy (kWh) & 7.7 & 7.4 & 5.1 & 20.2 \\
\hline Regen DC Energy (kWh) & 0.6 & 0.7 & 0.4 & 1.7 \\
\hline Net DC Energy $(\mathrm{kWh})$ & 7.1 & 6.7 & 4.7 & 18.5 \\
\hline Driving Cycle Discharge Information: & & & & \\
\hline Minimum Battery Voltage $(M)$ & 288.5 & 280.5 & 269.4 & 269.4 \\
\hline Maximum Battery Current $(A)$ & 217.1 & 218.1 & 151.7 & 218.1 \\
\hline Maximum Battery Power (kW) & 62.8 & 61.4 & 42.0 & 62.8 \\
\hline Driving Cycle Regen Information: & & & & \\
\hline Maximum Battery Voltage $(\mathrm{V})$ & 352.1 & 337.4 & 330.5 & 352.1 \\
\hline Maximum Battery Current $(A)$ & 78.1 & 77.4 & 79.9 & 79.9 \\
\hline Maximum Battery Power (kW) & 26.5 & 25.9 & 25.0 & 26.5 \\
\hline
\end{tabular}

Table 4b. Results Test No. LTDMF113 (separate cycles) subsequent to repairs made by TDM.

\begin{tabular}{|c|c|c|c|c|c|c|c|}
\hline \multicolumn{8}{|c|}{ Federal Urban Driving Schedule Test Results } \\
\hline \multirow[b]{3}{*}{ General: } & \multicolumn{7}{|c|}{ Cycle Number } \\
\hline & 1 & 2 & 3 & 4 & 5 & $6^{*}$ & Total \\
\hline & & & & & & & \\
\hline Distance $(\mathrm{km})$ & 12.1 & 12.1 & 12.1 & 12.0 & 12.0 & 4.9 & 65.1 \\
\hline Vehicle DC Energy Consumption (Wh/km) & 302 & 282 & 282 & 276 & 276 & 285 & 284 \\
\hline Gross Ampere-hours (Ah) & 12.7 & 12.0 & 12.2 & 12.1 & 12.3 & 5.3 & 66.6 \\
\hline Regen Ampere-hours (Ah) & 0.9 & 1.0 & 1.0 & 1.0 & 1.0 & 0.4 & 5.3 \\
\hline Net Ampere-hours (Ah) & 11.8 & 11.0 & 11.2 & 11.1 & 11.3 & 4.9 & 61.3 \\
\hline Gross DC Energy (kWh) & 4.0 & 3.7 & 3.7 & 3.6 & 3.6 & 1.5 & 20.2 \\
\hline Regen DC Energy (kWh) & 0.3 & 0.3 & 0.3 & 0.3 & 0.3 & 0.1 & 1.7 \\
\hline Net DC Energy (kWh) & 3.6 & 3.4 & 3.4 & 3.3 & 3.3 & 1.4 & 18.5 \\
\hline \multicolumn{8}{|l|}{ Driving Cycle Discharge Information: } \\
\hline Minimum Battery Voltage $(V)$ & 290.51 & 288.5 & 286.1 & 280.5 & 283.0 & 269.4 & 269.4 \\
\hline Maximum Battery Current $(A)$ & 207.5 & 217.1 & 214.5 & 218.1 & 140.4 & 151.7 & 218.1 \\
\hline Maximum Battery Power (kW) & 59.7 & 62.8 & 61.4 & 61.2 & 40.3 & 42.0 & 62.8 \\
\hline \multicolumn{8}{|l|}{ Driving Cycle Regen Information: } \\
\hline Maximum Battery Voltage $(V)$ & 352.1 & 340.8 & 337.4 & 333.9 & 330.5 & 327.8 & 352.1 \\
\hline Maximum Battery Current $(A)$ & 68.6 & 78.1 & 75.8 & 77.4 & 68.0 & 79.9 & 79.9 \\
\hline Maximum Battery Power (kW) & 23.4 & 26.5 & 25.5 & 25.9 & 22.4 & 25.0 & 26.5 \\
\hline * Partial cycle & & & & & & & \\
\hline
\end{tabular}


Table 5a. Results of UDDS test (combined cycles) with simulated AC load of 1.44 hp added to the $88 \mathrm{~km} / \mathrm{h}$ dynamometer set point for Test No. LTDMF122.

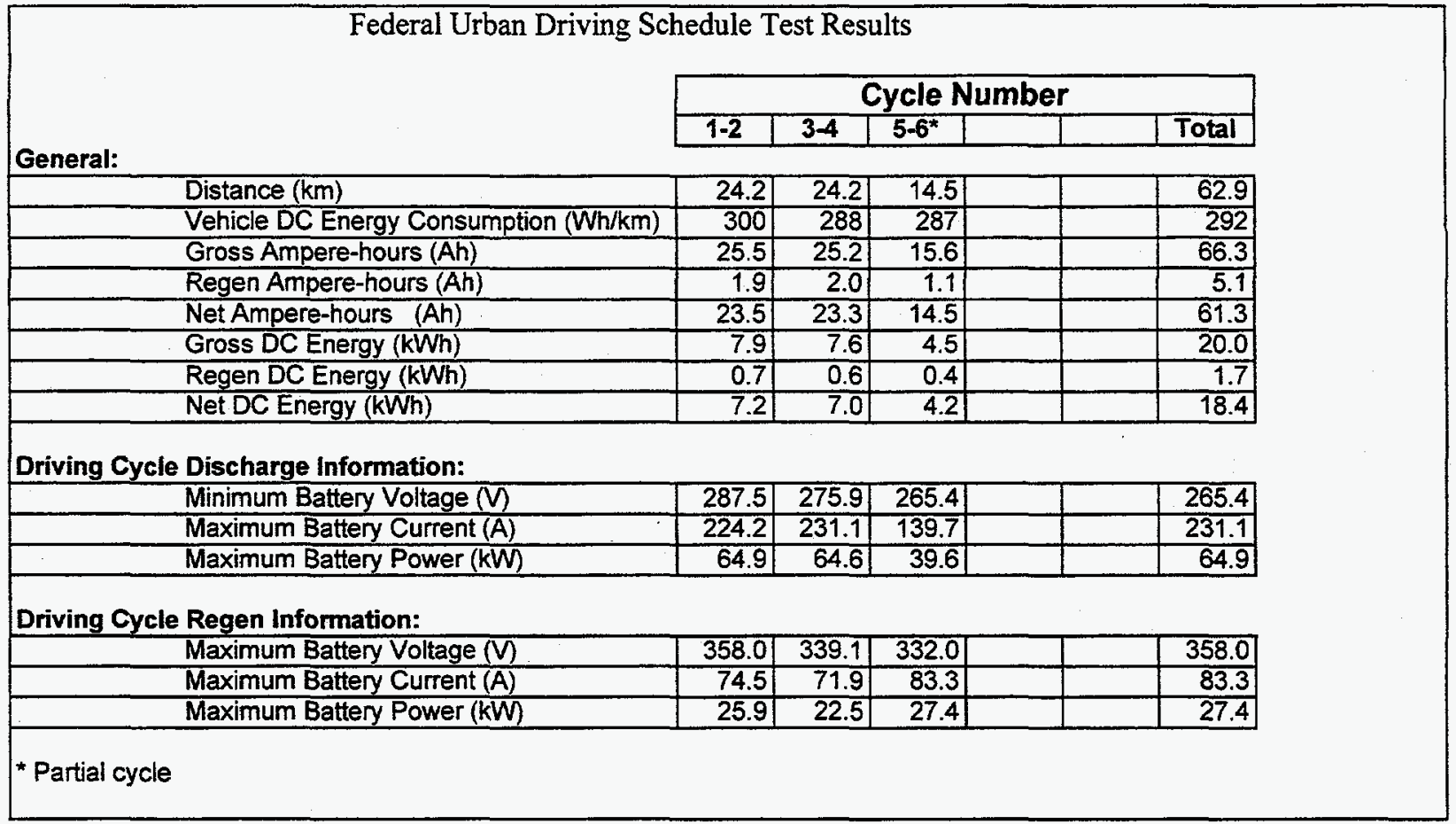

Table 5b. Results of UDDS test (separate cycles) with simulated AC load of $1.44 \mathrm{hp}$ added to the $88 \mathrm{~km} / \mathrm{h}$ dynamometer set point for Test No. LTDMF122.

Federal Urban Driving Schedule Test Results

\begin{tabular}{|c|c|c|c|c|c|c|c|}
\hline \multicolumn{8}{|c|}{ Federal Urban Driving Schedule Test Results } \\
\hline & \multicolumn{7}{|c|}{ Cycle Number } \\
\hline & 1 & 2 & 3 & 4 & 5 & $6^{*}$ & Total \\
\hline \multicolumn{8}{|l|}{ General: } \\
\hline Distance $(\mathrm{km})$ & 12.1 & 12.1 & 12.1 & 12.1 & 12.0 & 2.4 & 62.9 \\
\hline Vehicle DC Energy Consumption (Wh/km) & 308 & 291 & 290 & 285 & 288 & 281 & 292 \\
\hline Gross Ampere-hours (Ah) & 13.0 & 12.5 & 12.6 & 12.6 & 13.0 & 2.6 & 66.3 \\
\hline Regen Ampere-hours (Ah) & 1.0 & 1.0 & 1.0 & 1.0 & 1.0 & 0.1 & 5.1 \\
\hline Net Ampere-hours (Ah) & 12.0 & 11.5 & 11.6 & 11.6 & 12.0 & 2.5 & 61.3 \\
\hline Gross DC Energy (kWh) & 4.1 & 3.8 & 3.8 & 3.8 & 3.8 & 0.7 & 20.0 \\
\hline Regen DC Energy (kWh) & 0.3 & 0.3 & 0.3 & 0.3 & 0.3 & 0.0 & 1.7 \\
\hline Net DC Energy (kWh) & 3.7 & 3.5 & 3.5 & 3.4 & 3.5 & 0.7 & 18.4 \\
\hline \multicolumn{8}{|l|}{ Driving Cycle Discharge Information: } \\
\hline Minimum Battery Voltage $(V)$ & 289.2 & 287.5 & 280.7 & 275.9 & 271.4 & 265.4 & 265.4 \\
\hline Maximum Battery Current $(A)$ & 224.2 & 220.9 & 231.1 & 223.7 & 139.7 & 113.0 & 231.1 \\
\hline Maximum Battery Power (kW) & 64.9 & 63.5 & 64.6 & 61.7 & 39.6 & 30.5 & 64.9 \\
\hline \multicolumn{8}{|l|}{ Driving Cycle Regen Information: } \\
\hline Maximum Battery Voltage (V) & 358.0 & 342.9 & 339.1 & 334.4 & 332.0 & 329.2 & 358.0 \\
\hline Maximum Battery Current (A) & 74.5 & 74.3 & 66.9 & 71.9 & 77.8 & 83.3 & 83.3 \\
\hline Maximum Battery Power (kW) & 25.9 & 25.3 & 22.5 & 22.5 & 24.5 & 27.4 & 27.4 \\
\hline
\end{tabular}


Table 6a. Results of UDDS test (separate cycles) with air conditioning on "maximum, "minimum," and "off" for Test No. LTDMFD20.

\begin{tabular}{|c|c|c|c|c|c|c|c|}
\hline \multicolumn{8}{|c|}{ Federal Urban Driving Schedule Test Results } \\
\hline \multirow[b]{3}{*}{ General: } & \multicolumn{7}{|c|}{ Cycle Number } \\
\hline & 1 & 2 & 3 & 4 & 5 & $6^{*}$ & Total \\
\hline & & & & & & & \\
\hline Distance $(\mathbf{k m})$ & 12.1 & 12.1 & 12.1 & 12.1 & 12.0 & 4.0 & 64.4 \\
\hline Vehicle DC Energy Consumption (Wh/km) & 348 & 308 & 331 & 324 & 278 & 265 & 315 \\
\hline Gross Ampere-hours (Ah) & 14.3 & 12.8 & 13.9 & 13.9 & 12.5 & 4.2 & 71.7 \\
\hline Regen Ampere-hours (Ah) & 0.8 & 0.8 & 0.8 & 0.8 & 0.9 & 0.3 & 4.4 \\
\hline Net Ampere-hours (Ah) & 13.5 & 12.0 & 13.2 & 13.1 & 11.5 & 3.9 & 67.3 \\
\hline Gross DC Energy (kWh) & 4.5 & 4.0 & 4.3 & 4.2 & 3.7 & 1.2 & 21.7 \\
\hline Regen DC Energy (kWh) & 0.3 & 0.3 & 0.3 & 0.3 & 0.3 & 0.1 & 1.4 \\
\hline Net DC Energy (kWh) & 4.2 & 3.7 & 4.0 & 3.9 & 3.3 & 1.1 & 20.3 \\
\hline \multicolumn{8}{|l|}{ Driving Cycie Discharge Information: } \\
\hline Minimum Battery Voltage $(\mathrm{V})$ & 284.3 & 289.2 & 284.5 & 277.6 & 274.3 & 267.0 & 267.0 \\
\hline Maximum Battery Current (A) & 290.2 & 222.1 & 224.2 & 226.0 & 145.4 & 143.0 & 290.2 \\
\hline Maximum Battery Power (kW) & 82.5 & 62.7 & 63.8 & 62.8 & 41.3 & 38.7 & 82.5 \\
\hline \multicolumn{8}{|l|}{ Driving Cycle Regen Information: } \\
\hline Maximum Battery Voltage $(V)$ & 343.2 & 338.9 & 334.8 & 333.2 & 329.7 & 326.2 & 343.2 \\
\hline Maximum Battery Current (A) & 55.8 & 60.5 & 56.3 & 69.8 & 63.6 & 66.9 & 69.8 \\
\hline Maximum Battery Power (kW) & 19.1 & 20.4 & 18.7 & 23.2 & 20.9 & 21.5 & 23.2 \\
\hline \multicolumn{8}{|l|}{ * Partial cycle } \\
\hline $\begin{array}{l}\text { Cycles 1-2: AC on maximum } \\
\text { Cycles 3-4: AC on minimum } \\
\text { Cycles 5-6: AC off }\end{array}$ & & & & & & & \\
\hline
\end{tabular}

Table 6b. Results of UDDS test (combined cycles) with air conditioning on "maximum, "minimum," and "off" for Test No. LTDMFD20.

\begin{tabular}{|c|c|c|c|c|}
\hline \multicolumn{5}{|c|}{ Federal Urban Driving Schedule Test Results } \\
\hline & & & ycle N & \\
\hline & $1-2$ & $3-4$ & $5-6^{*}$ & Total \\
\hline \multicolumn{5}{|l|}{ General: } \\
\hline Distance (km) & 24.2 & 24.2 & 16.1 & 64.4 \\
\hline Vehicle DC Energy Consumption (Wh/km) & 328 & 328 & 274 & 315 \\
\hline Gross Ampere-hours (Ah) & 27.2 & 27.9 & 16.6 & 71.7 \\
\hline Regen Ampere-hours (Ah) & 1.6 & 1.6 & 1.2 & 4.4 \\
\hline Net Ampere-hours (Ah) & 25.6 & 26.3 & 15.4 & 67.3 \\
\hline Gross DC Energy $(\mathrm{kWh})$ & 8.5 & 8.4 & 4.8 & 21.7 \\
\hline Regen DC Energy (kWh) & 0.5 & 0.5 & 0.4 & 1.4 \\
\hline Net DC Energy (kWh) & 7.9 & 7.9 & 4.4 & 20.3 \\
\hline \multicolumn{5}{|l|}{ Driving Cycle Discharge Information: } \\
\hline Minimum Battery Voltage $(V)$ & 284.3 & 277.6 & 267.0 & 267.0 \\
\hline Maximum Battery Current (A) & 290.2 & 226.0 & 145.4 & 290.2 \\
\hline Maximum Battery Power (kW) & 82.5 & 63.8 & 41.3 & 82.5 \\
\hline \multicolumn{5}{|l|}{ Driving Cycle Regen Information: } \\
\hline Maximum Battery Voltage ( $V$ ) & 343.2 & 334.8 & 329.7 & 343.2 \\
\hline Maximum Battery Current (A) & 60.5 & 69.8 & 66.9 & 69.8 \\
\hline Maximum Battery Power (kW) & 20.4 & 23.2 & 21.5 & 23.2 \\
\hline \multicolumn{5}{|l|}{ * Partial cycle } \\
\hline $\begin{array}{l}\text { Cycles 1-2: } A C \text { on maximum } \\
\text { Cycles 3-4: AC on minimum } \\
\text { Cycles 5-6: } A C \text { off }\end{array}$ & & & & \\
\hline
\end{tabular}


Table 7. Results of Highway Fuel Economy Driving Schedule (HFEDS) Test No. LTDMHD17.

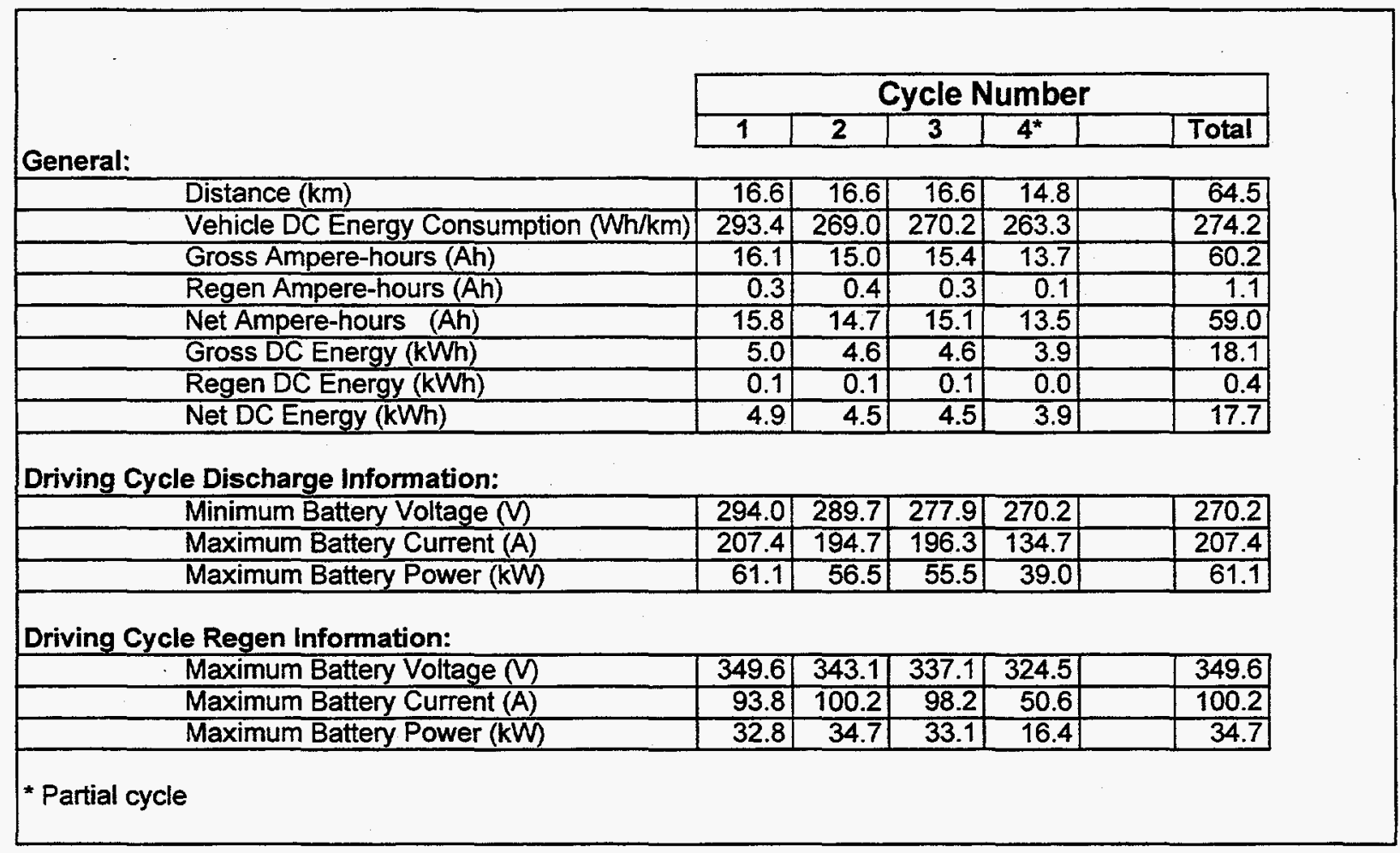




\section{All-Electric (combined UDDS/HFEDS) Tests}

Two all-electric (combined UDDS/HFEDS) driving cycle tests were performed (test numbers LTDMA106 and LTDMA108). The results of these tests are summarized in Tables 8a and $8 b$, and $9 \mathrm{a}$ and $9 \mathrm{~b}$.

\section{LA-92 Driving Cycle Tests}

One LA-92 driving cycle test was performed (test numbers LTDMLD18). The results of this test is summarized in Table 10. 
Table 8a. Results of All-Electric Driving Schedule [combined UDDS/HFEDS (Cycle 1 \& 2)] for Test No. LTDMA106.

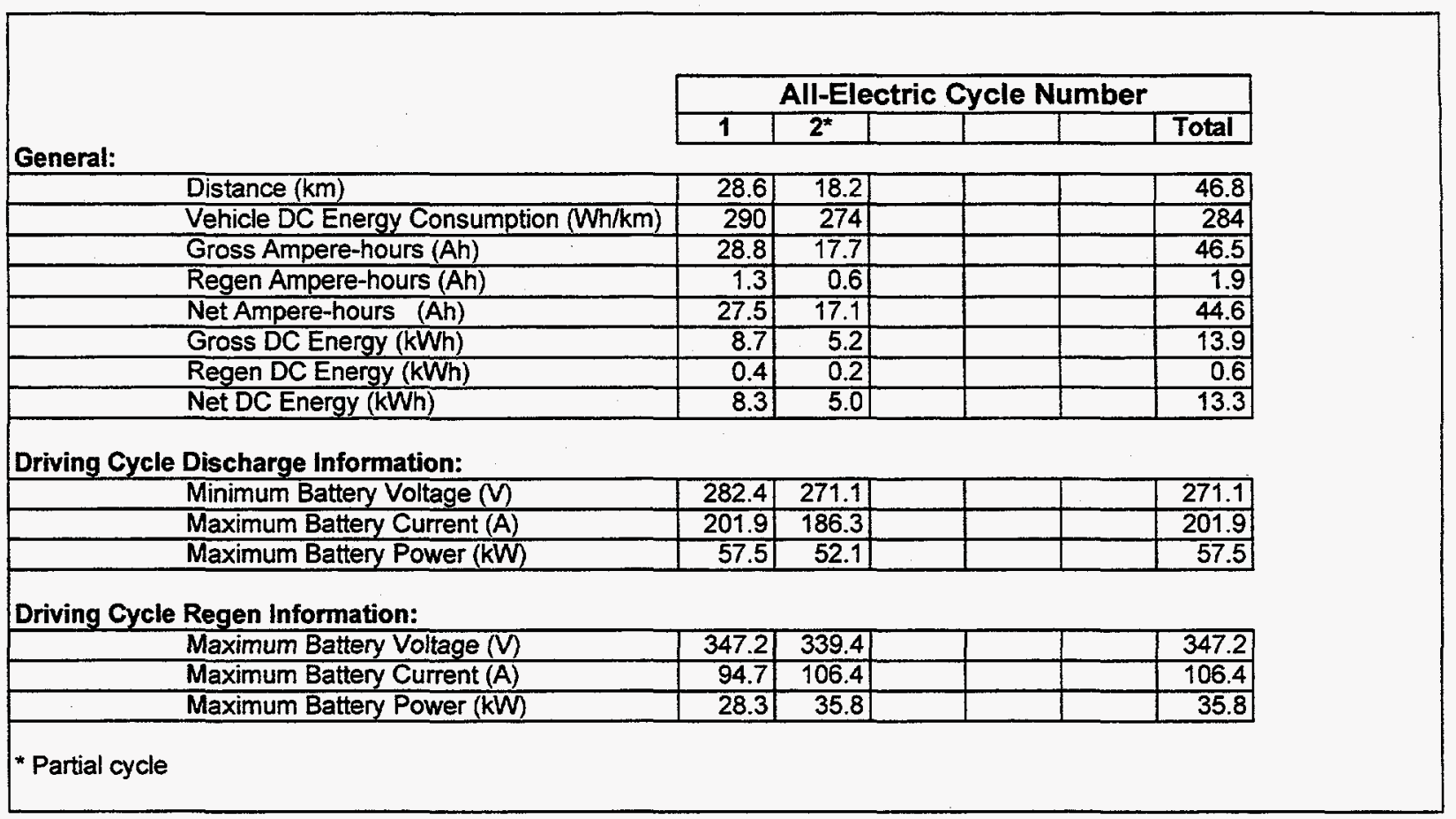

Table 8b. Results of All-Electric (combined UDDS/HFEDS) for Test No. LTDMA1

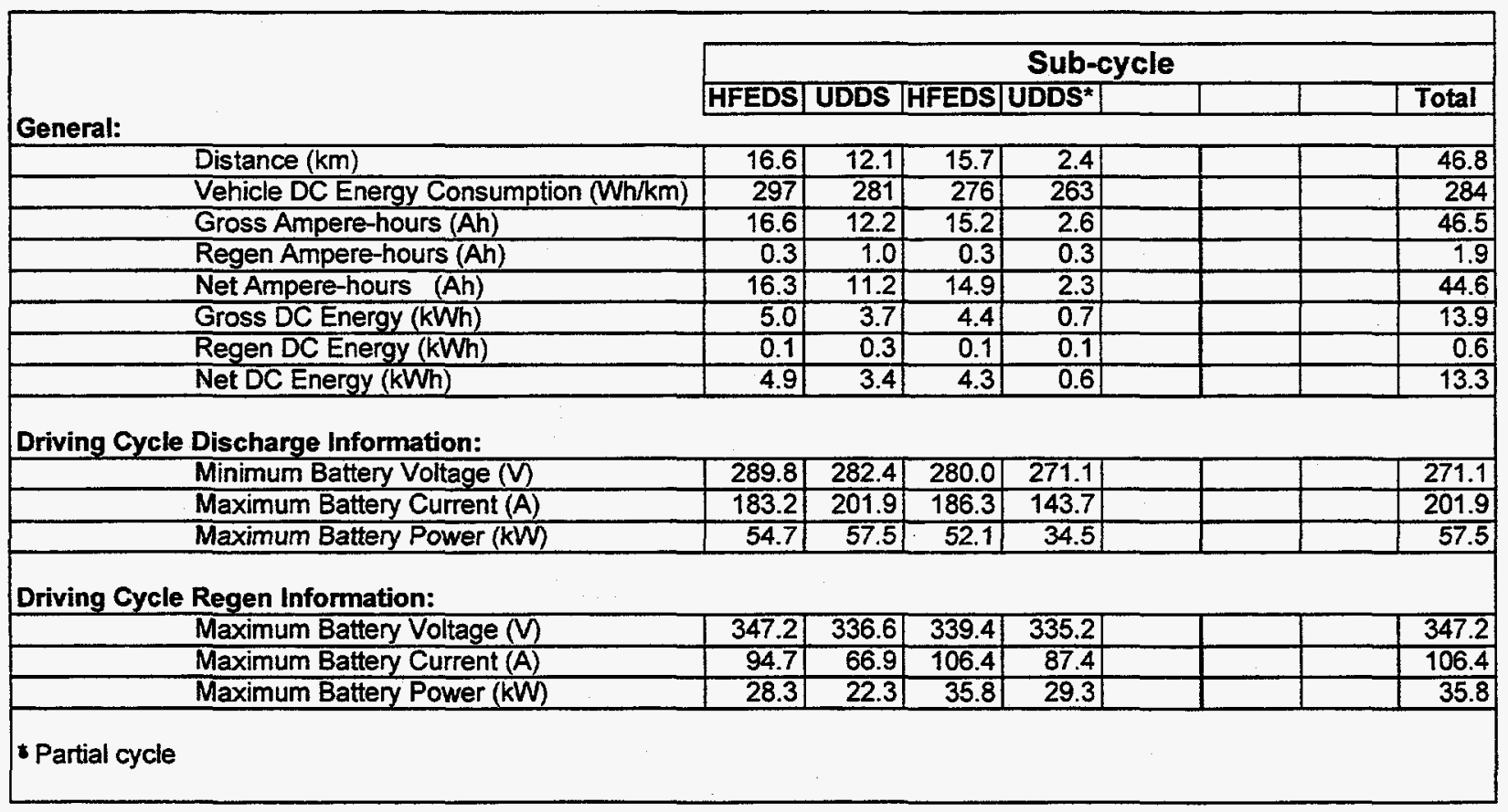


Table 9a. Results of All-Electric [combined UDDS/HFEDS (Cycle 1 and 2)] for Test No. LTDMA108.

\begin{tabular}{|c|c|c|c|}
\hline \multirow[b]{3}{*}{ General: } & \multicolumn{3}{|c|}{ All-Electric Cycle Number } \\
\hline & 1 & $2^{*}$ & Total \\
\hline & \\
\hline Distance $(\mathrm{km})$ & 28.7 & 17.0 & 45.7 \\
\hline Vehicle DC Energy Consumption (Wh/km) & 289 & 277 & 284 \\
\hline Gross Ampere-hours (Ah) & 12.3 & 16.4 & 28.8 \\
\hline Regen Ampere-hours (Ah) & 17.1 & 0.4 & 17.5 \\
\hline Net Ampere-hours (Ah) & 15.9 & 16.0 & 31.9 \\
\hline Gross DC Energy (kWh) & 8.7 & 4.9 & 13.6 \\
\hline Regen DC Energy (kWh) & 0.4 & 0.1 & 0.6 \\
\hline Net DC Energy (kWh) & 8.3 & 4.7 & 13.0 \\
\hline \multicolumn{4}{|l|}{ Driving Cycle Discharge Information: } \\
\hline Minimum Battery Voltage $(M)$ & 286.7 & 278.0 & 278.0 \\
\hline Maximum Battery Current (A) & 209.3 & 136.9 & 209.3 \\
\hline Maximum Battery Power (kW) & 61.0 & 39.8 & 61.0 \\
\hline \multicolumn{4}{|l|}{ Driving Cycle Regen Information: } \\
\hline Maximum Battery Voltage $(M)$ & 348.0 & 338.5 & 348.0 \\
\hline Maximum Battery Current (A) & 77.1 & 96.2 & 96.2 \\
\hline Maximum Battery Power $(\mathrm{kW})$ & 26.8 & 34.0 & 34.0 \\
\hline
\end{tabular}

Table 9b. Results of All-electric (combined UDDS/HFEDS) for Test No. LTDMA108.

\begin{tabular}{|c|c|c|c|c|c|}
\hline \multirow[b]{3}{*}{ General: } & \multicolumn{5}{|c|}{ Sub-cycle } \\
\hline & \multirow{2}{*}{ HFEDS } & \multirow[t]{2}{*}{ UDDS } & \multirow[t]{2}{*}{ HFEDS } & \multirow[t]{2}{*}{ UDDS $^{\star}$} & \multirow[t]{2}{*}{ Total } \\
\hline & & & & & \\
\hline Distance (km) & 16.6 & 12.1 & 16.5 & 0.5 & 45.7 \\
\hline Vehicle DC Energy Consumption (Wh/km) & 297 & 277 & 277 & 280 & 284 \\
\hline Gross Ampere-hours (Ah) & 0.4 & 12.0 & 15.8 & 0.6 & 28.8 \\
\hline Regen Ampere-hours (Ah) & 16.1 & 1.0 & 0.3 & 0.1 & 17.5 \\
\hline Net Ampere-hours (Ah) & 4.9 & 11.0 & 15.5 & 0.5 & 31.9 \\
\hline Gross DC Energy (kWh) & 5.0 & 3.7 & 4.7 & 0.2 & 13.6 \\
\hline Regen DC Energy (kWh) & 0.1 & 0.3 & 0.1 & 0.0 & 0.6 \\
\hline Net DC Energy (kWh) & 4.9 & 3.4 & 4.6 & 0.2 & 13.0 \\
\hline \multicolumn{6}{|l|}{ Driving Cycle Discharge Information: } \\
\hline Minimum Battery Voltage $(\mathrm{V})$ & 287.9 & 286.7 & 278.0 & 292.9 & 278.0 \\
\hline Maximum Battery Current (A) & 209.3 & 206.8 & 136.9 & 73.4 & 209.3 \\
\hline Maximum Battery Power (kW) & 61.0 & 59.5 & 39.8 & 21.5 & 61.0 \\
\hline \multicolumn{6}{|l|}{ Driving Cycle Regen Information: } \\
\hline Maximum Battery Voltage ( $\mathrm{V}$ ) & 348.0 & 338.9 & 338.5 & 322.8 & 348.0 \\
\hline Maximum Battery Current (A) & 77.1 & 67.0 & 96.2 & 42.8 & 96.2 \\
\hline Maximum Battery Power (kW) & 26.8 & 22.5 & 34.0 & 13.8 & 34.0 \\
\hline * Partial cycle & & & & & \\
\hline
\end{tabular}


Table 10. Results of LA-92 Driving Cycle for Test No. LTDMLD18.

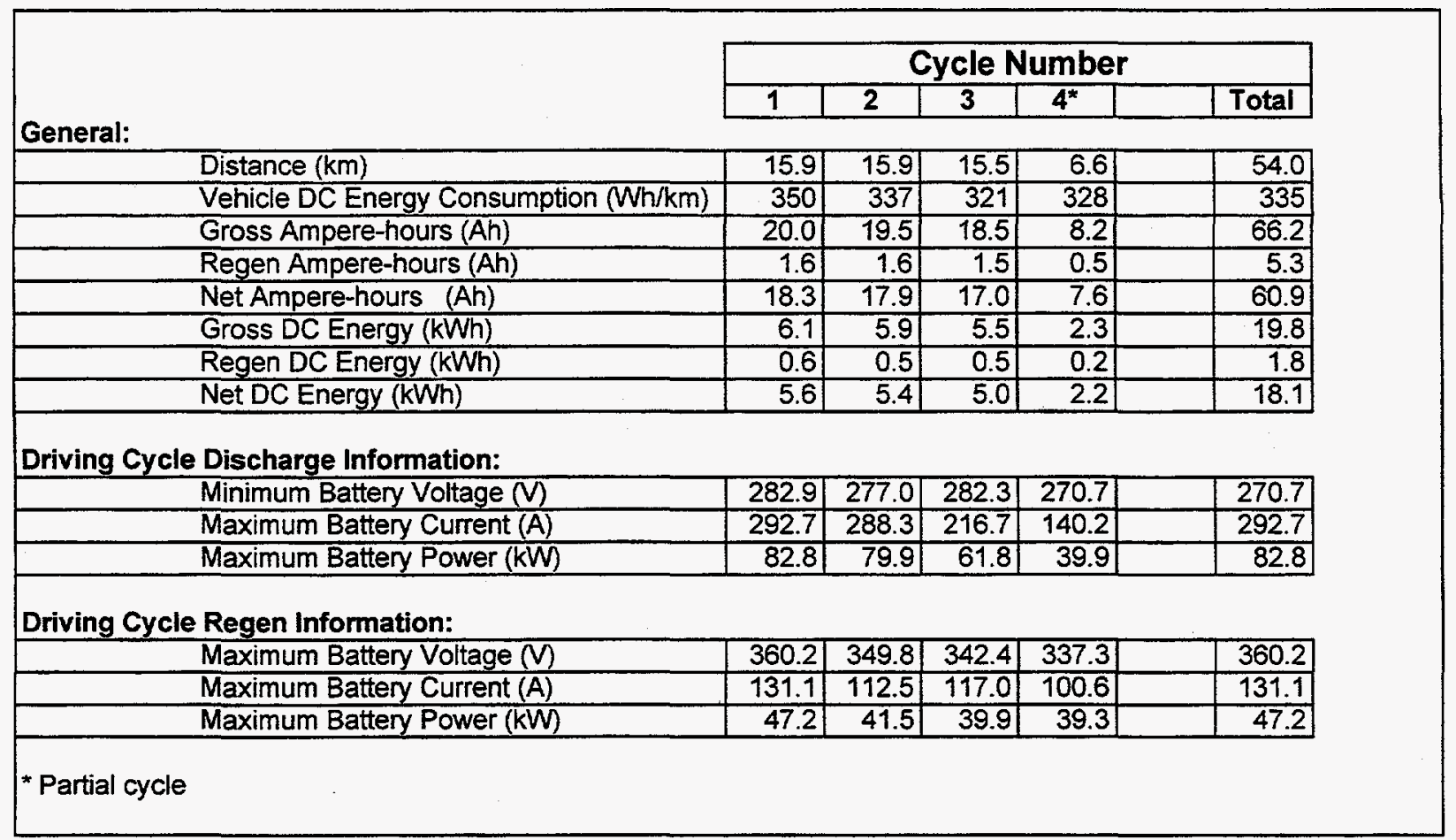




\section{OTHER TESTS}

Several other standard performance were conducted, including tests to determine the vehicle DC energy consumption at constant speeds, maximum effort acceleration times from a standing start and gradeability-at-speed.

\section{Energy Economy Tests}

Several constant speed trials were performed on a smooth level public roadway. The intent of these tests was to collect data to verify the loads programmed into the dynamometer. A set of constant speed tests was then performed on the dynamometer and compared to the results of the tests performed on the road. A graph of the energy consumption at various speeds measured on the road and on the dynamometer is shown in Figure 7. For reference, the energy consumption reported by TDM is also shown. The INEEL tests were performed prior to the vehicle repairs. The battery state-of-charge at the time of on-road measurements were made and the battery state-of-charge during the TDM measurements was not determined. The energy consumption determined for the on-road case is generally less than that determined on the dynamometer. This result is most likely due to the effect of the rotating driveline components which were not disconnected during coastdown trials, resulting in an additional load programmed into the dynamometer that is not present on the road.

The dynamometer energy economy tests was repeated subsequent to the repairs made by TDM. The graphs in Figures 8 and 9 show the vehicle DC energy economy at various speeds and states-of-charge both prior to and after vehicle repairs. The energy consumption values and traction battery power corresponding to Figure 9 are given in Table 11.

\section{Acceleration Tests}

One maximum effort acceleration tests was performed on the dynamometer to determine the best effort acceleration characteristics of the vehicle (test number LTDMB131). The maximum effort acceleration was measured at three different beginning battery states-of-charge. Table 12 and Figure 10 shows the averaged acceleration times to reach given speeds as a function of the battery depth-of-discharge. 


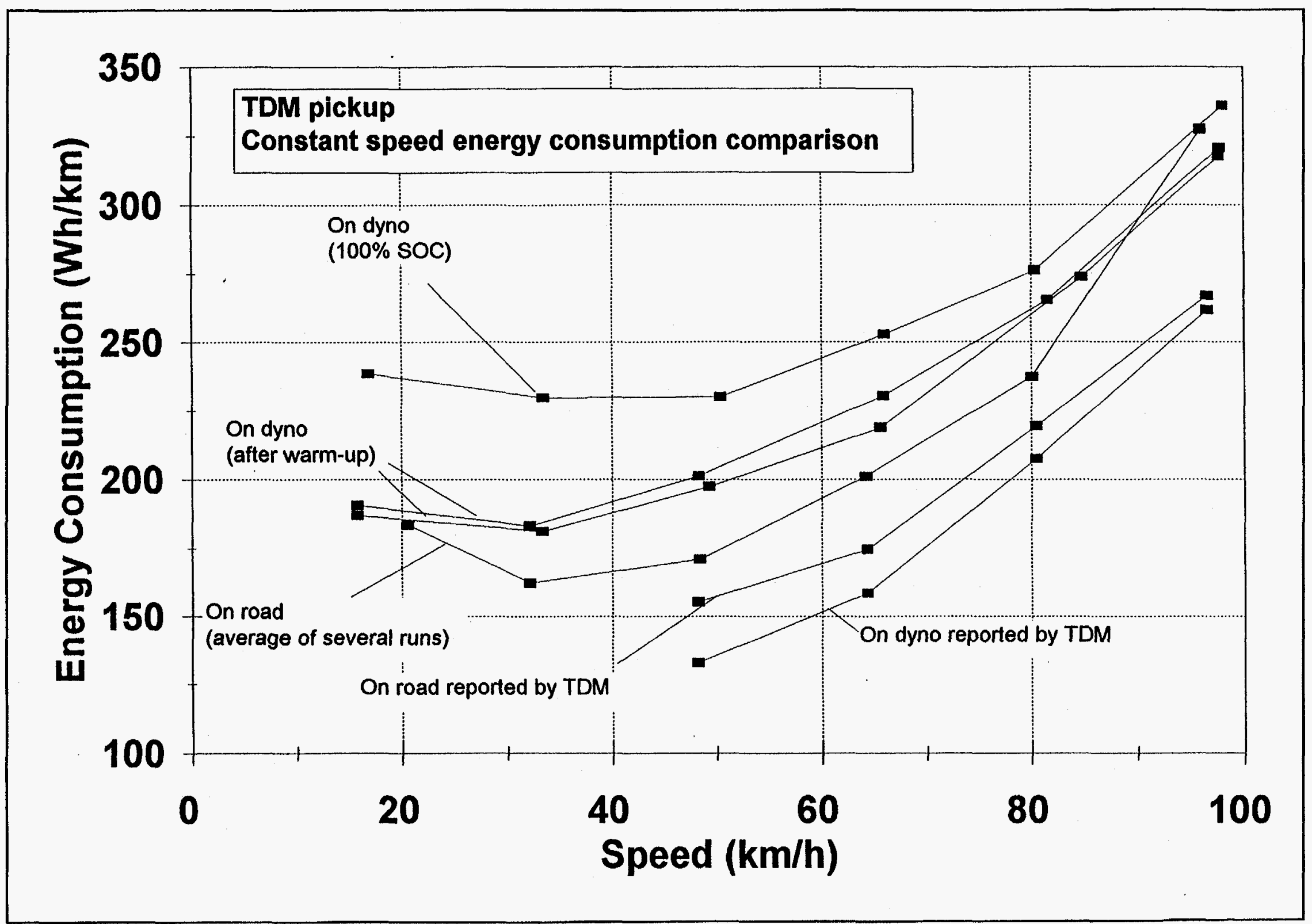

Figure 7. Comparison of energy consumption measured (1) on the road at the INEEL, (2) on the dynamometer at the INEEL, and (3) as reported by TDM. 


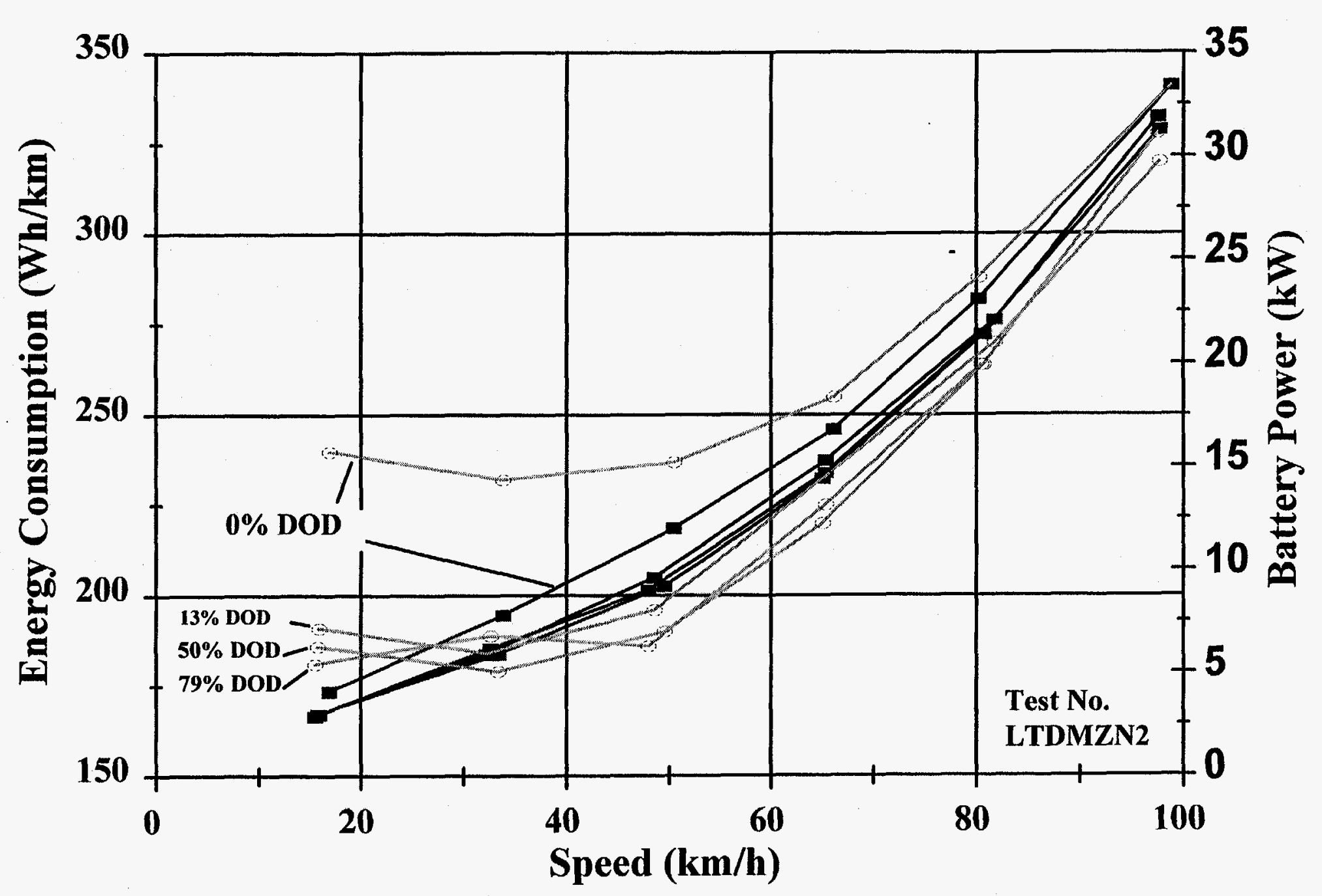

TDM Ranger Pickup Truck

Energy Economy Test

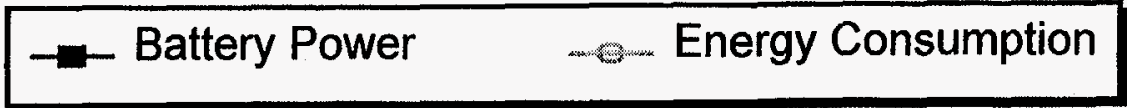

Figure 8. Results of energy consumption tests prior to vehicle repairs. 


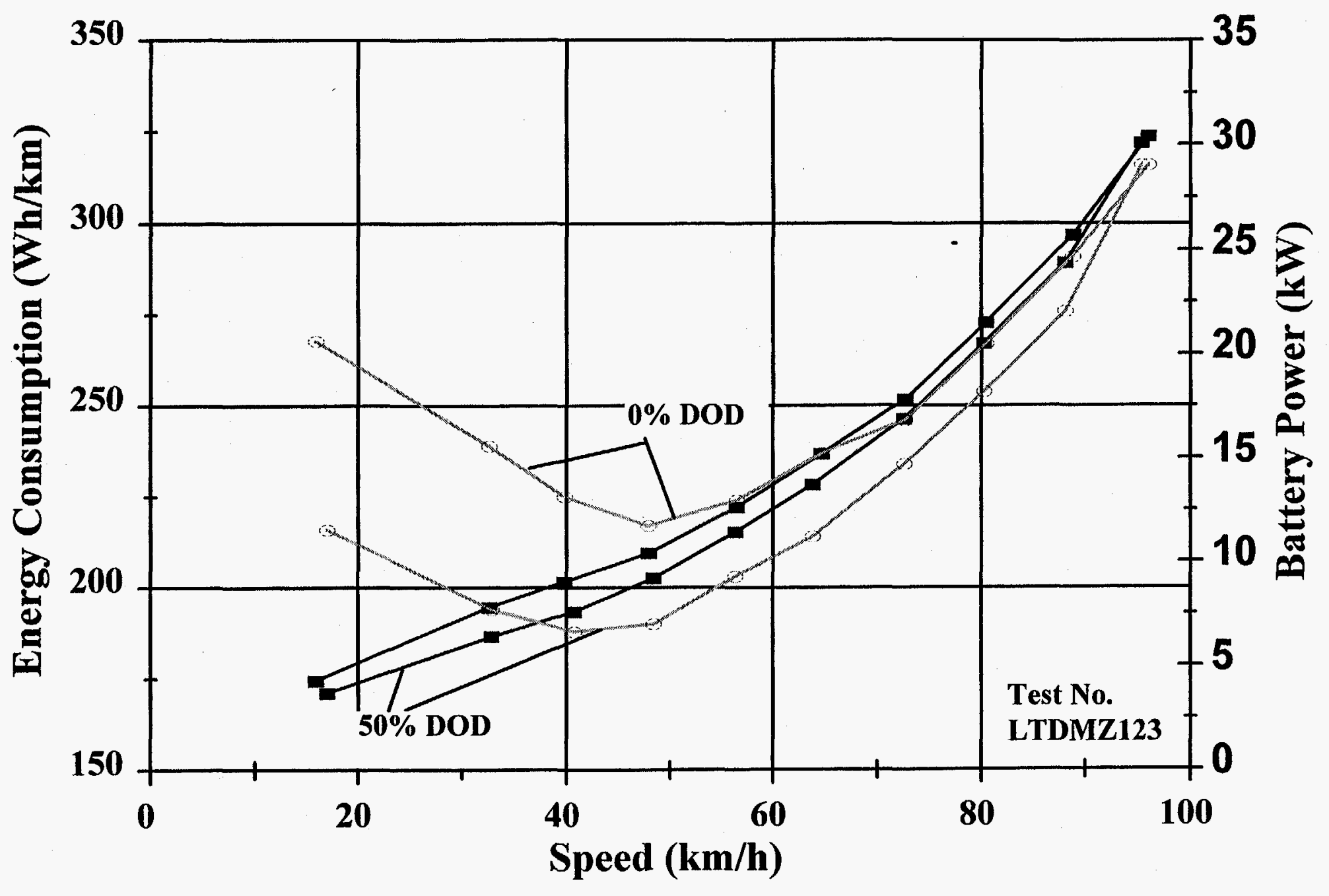

TDM Ranger Pickup Truck Energy Economy Test 
Table 11. Acceleration times to reach a specified speed and calculated gradability-at-speed resulting from test number LTDMB131.

\begin{tabular}{|c|c|c|c|c|c|c|}
\hline \multirow{2}{*}{ Speed $(\mathbf{k m} / \mathrm{h})$} & \multicolumn{3}{|c|}{$\begin{array}{c}\text { Time (s) to attain speed at } \\
\text { various traction battery } \\
\text { depths-of-discharge }\end{array}$} & \multicolumn{2}{|c|}{$\begin{array}{c}\text { Maximum Grade at Speed } \\
\text { (\%) at various traction } \\
\text { battery depths-of-discharge }\end{array}$} \\
\cline { 2 - 7 } & $\mathbf{2 . 8 \%}$ & $\mathbf{4 5 . 3 \%}$ & $\mathbf{6 6 . 9} \%$ & $\mathbf{2 . 8 \%}$ & $\mathbf{4 5 . 3 \%}$ & $\mathbf{6 6 . 9 \%}$ \\
\hline 24 & 2.1 & 2.1 & 3.7 & 39.2 & 38.4 & 16.3 \\
\hline 32 & 2.8 & 2.9 & 5.1 & 39.0 & 28.7 & 15.4 \\
\hline 40 & 3.5 & 3.8 & 7.0 & 27.0 & 21.4 & 11.1 \\
\hline 48 & 4.5 & 5.1 & 9.5 & 20.7 & 16.6 & 8.7 \\
\hline 56 & 5.8 & 6.7 & 12.7 & 15.1 & 12.2 & 5.5 \\
\hline 64 & 7.6 & 8.8 & 17.1 & 11.9 & 10.1 & 4.6 \\
\hline 72 & 9.9 & 11.5 & 23.0 & 8.7 & 9.1 & 3.4 \\
\hline 80 & 13.0 & 14.9 & 31.6 & 6.0 & 5.5 & 2.3 \\
\hline 88 & 17.6 & 19.9 & 47.0 & 4.0 & 3.7 & 0.9 \\
\hline 96 & 24.6 & 28.2 & & 2.6 & 2.3 & \\
\hline
\end{tabular}


Table 12. Traction battery DC energy consumption at steady speeds derived from test number LTDMZ123.

\begin{tabular}{|c|c|c|c|c|}
\hline \multirow{2}{*}{ Speed $(\mathbf{k m} / \mathbf{h})$} & \multicolumn{2}{|c|}{$\begin{array}{c}\text { Starting at 0\% traction battery } \\
\text { depth-of-discharge }\end{array}$} & $\begin{array}{c}\text { Starting at 50\% traction battery } \\
\text { depth-of-discharge }\end{array}$ \\
\cline { 2 - 5 } & $\begin{array}{c}\text { Energy } \\
\text { Consumption } \\
(\mathbf{D C} \mathbf{W h} / \mathbf{k m})\end{array}$ & $\begin{array}{c}\text { Battery Power } \\
\text { (DC } \mathbf{~} \mathbf{W})\end{array}$ & $\begin{array}{c}\text { Energy } \\
\text { Consumption } \\
\text { DC Wh/km }\end{array}$ & $\begin{array}{c}\text { Battery Power } \\
\mathbf{D C} \mathbf{~ k W}\end{array}$ \\
\hline 16 & 268 & 4.3 & 216 & 3.7 \\
\hline 32 & 239 & 7.8 & 195 & 6.4 \\
\hline 40 & 225 & 9.0 & 188 & 7.7 \\
\hline 48 & 217 & 10.4 & 190 & 9.2 \\
\hline 56 & 223 & 12.6 & 201 & 11.3 \\
\hline 64 & 233 & 15.0 & 216 & 13.8 \\
\hline 72 & 246 & 17.8 & 231 & 16.8 \\
\hline 80 & 267 & 21.5 & 253 & 20.3 \\
\hline 88 & 288 & 25.4 & 276 & 24.4 \\
\hline 96 & 315 & 30.2 & 316 & 30.1 \\
\hline
\end{tabular}




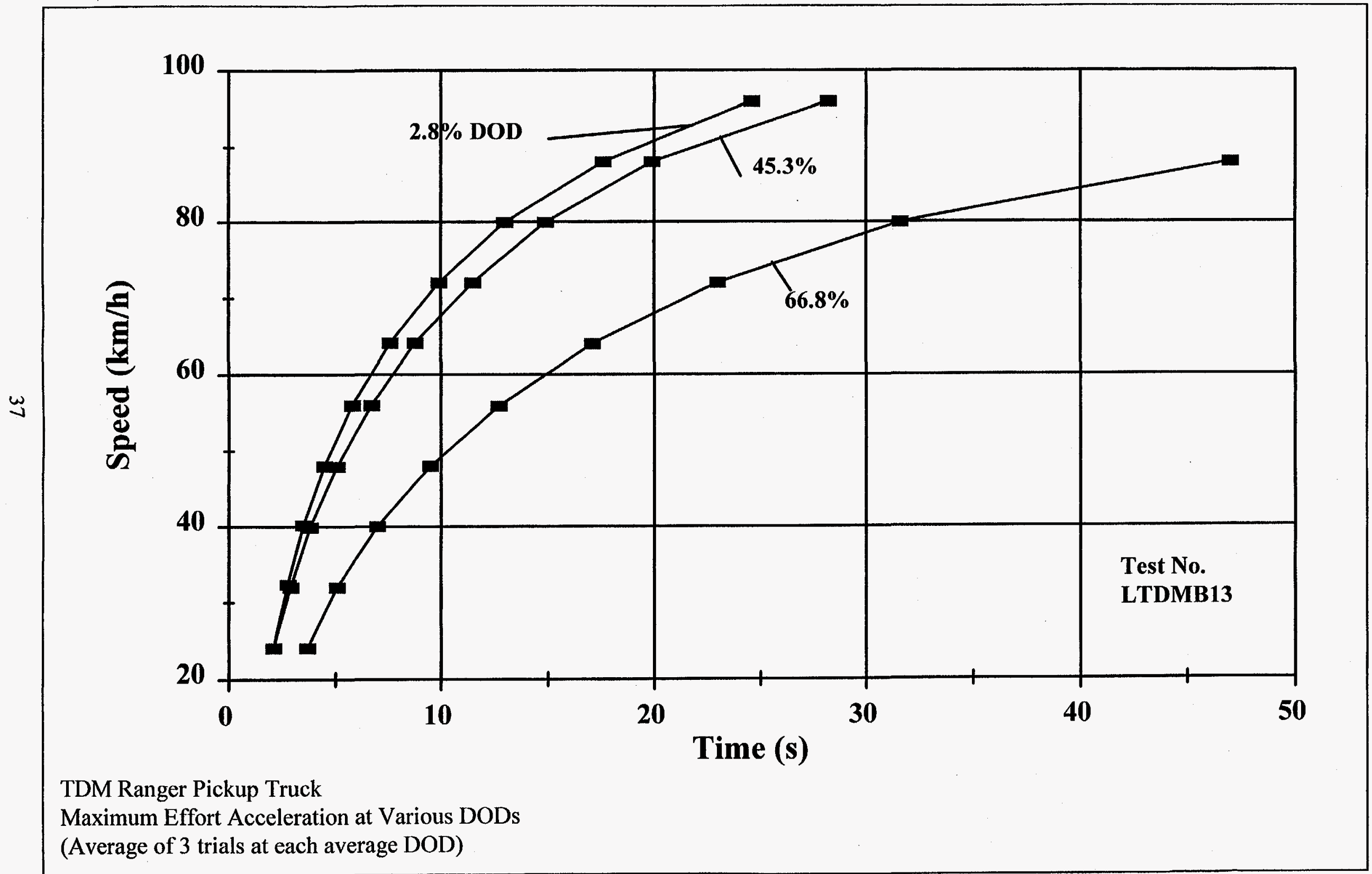

Figure 10. Maximum effort acceleration time to attain speed at various traction battery depths-of-discharge. 
This data may be used to calculate the gradeability at speed characteristics of the vehicle according to the SAE recommended practice SAE J1666. The resultant "percent Grade" represents the maximum grade that the vehicle can ascend at the given speed and battery depthof-discharge. This analysis is shown in Table 12 and Figure 11.

\section{Battery Recharge Measurements}

Data was acquired during several battery recharges. Due to equipment problems, we were unable to measure battery recharges for all tests. Additionally, $\mathrm{AC}$ power and energy were not measured until near the end of the test program. Figure 12 shows the momentary charger efficiency during the battery recharge following a UDDS test. As shown, the charger efficiency is approximately $65 \%$ during the constant current portion of the recharge, and drops to between $20 \%$ and $45 \%$ during the "top-off" portion of the recharge. The average charger efficiency for the complete recharge is $60 \%$. 


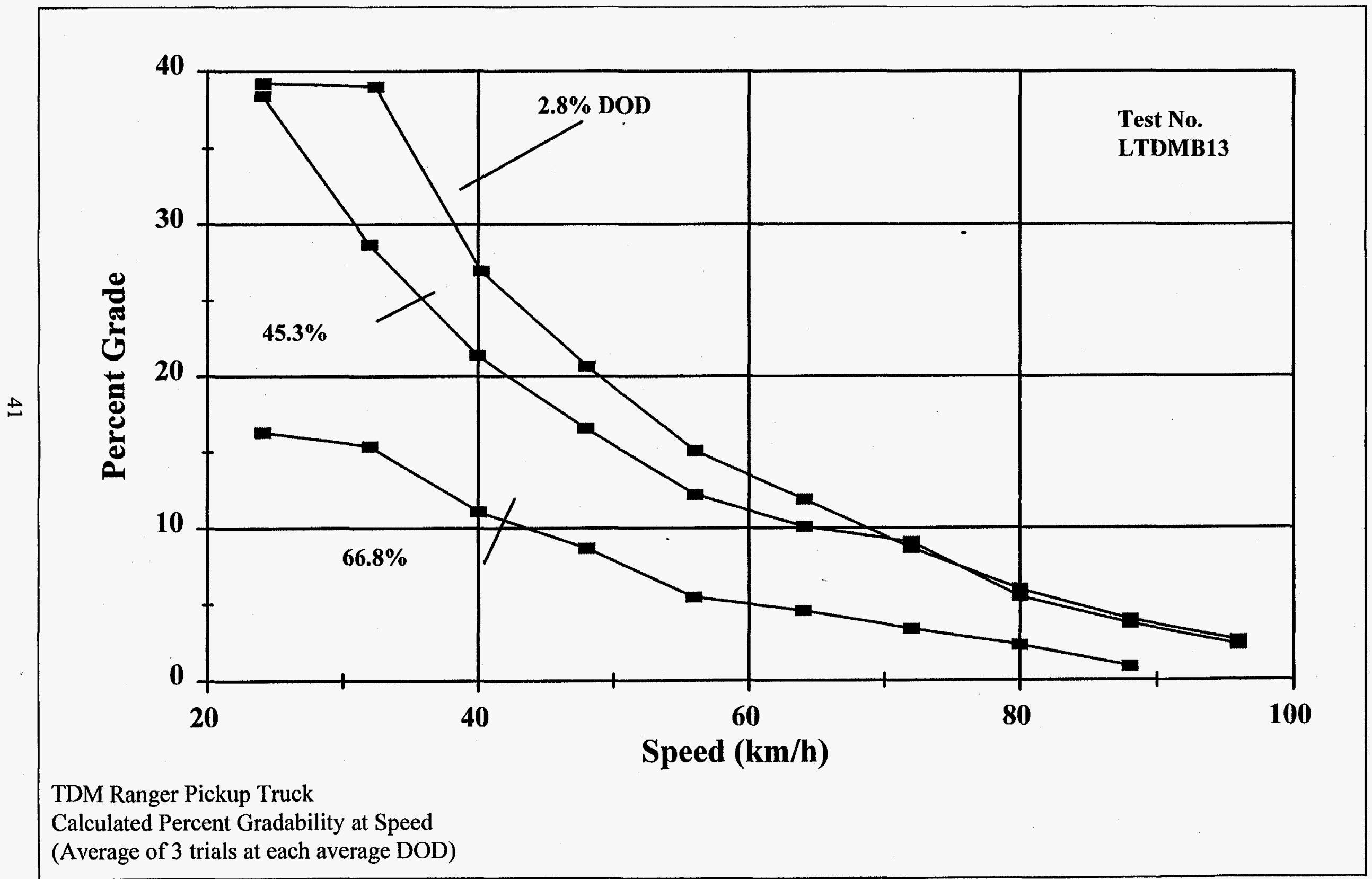

Figure 11. Percent gradeability at speed derived from maximum effort acceleration tests. 


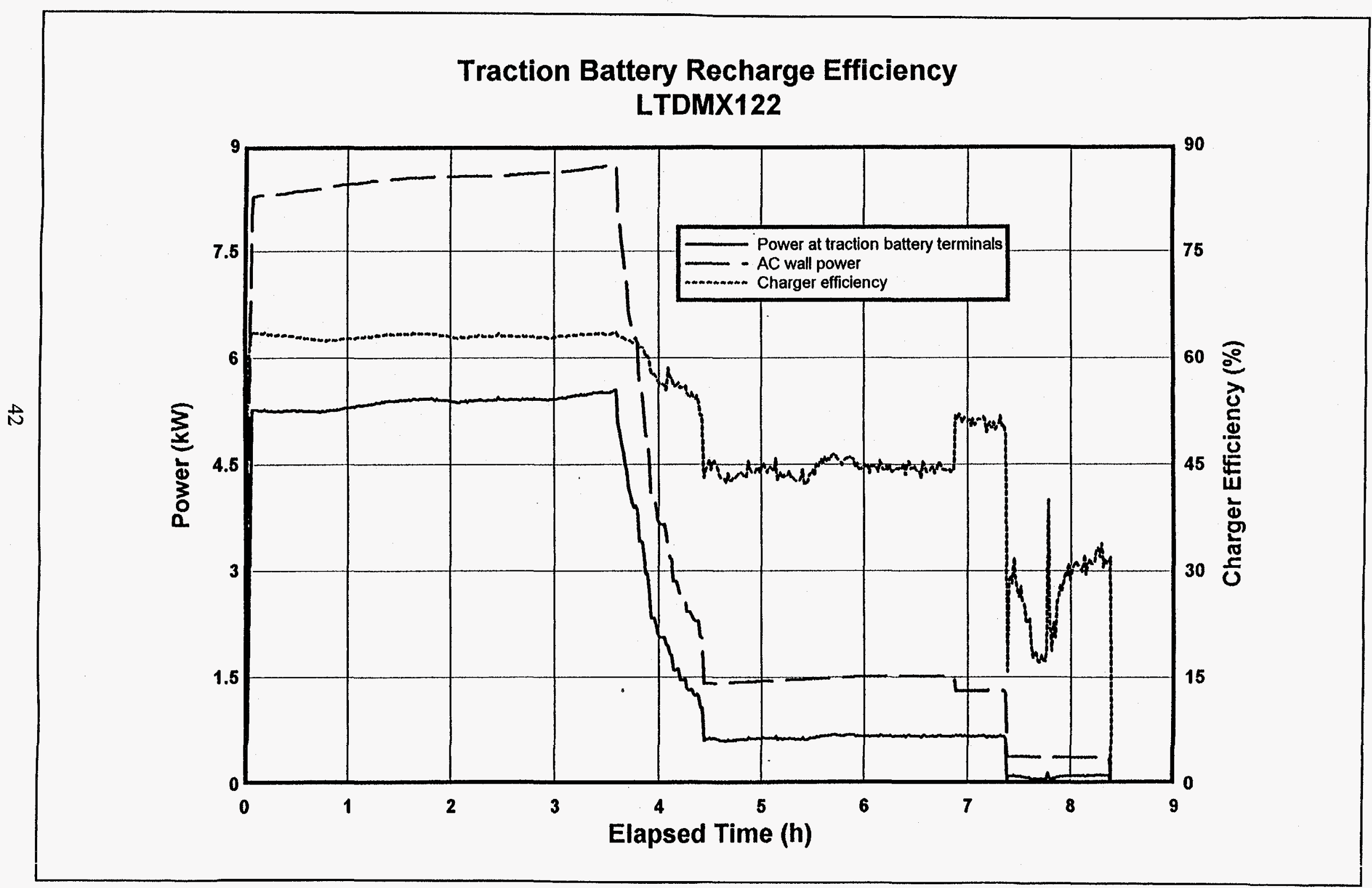

Figure 12. Charger efficiency during battery recharge. 